\title{
The Potential of Breccia Pipes in the National Tank Area, Hualapai Indian Reservation, Arizona
}

\section{U.S. GEOLOGICAL SURVEY BULLETIN 1683-B}

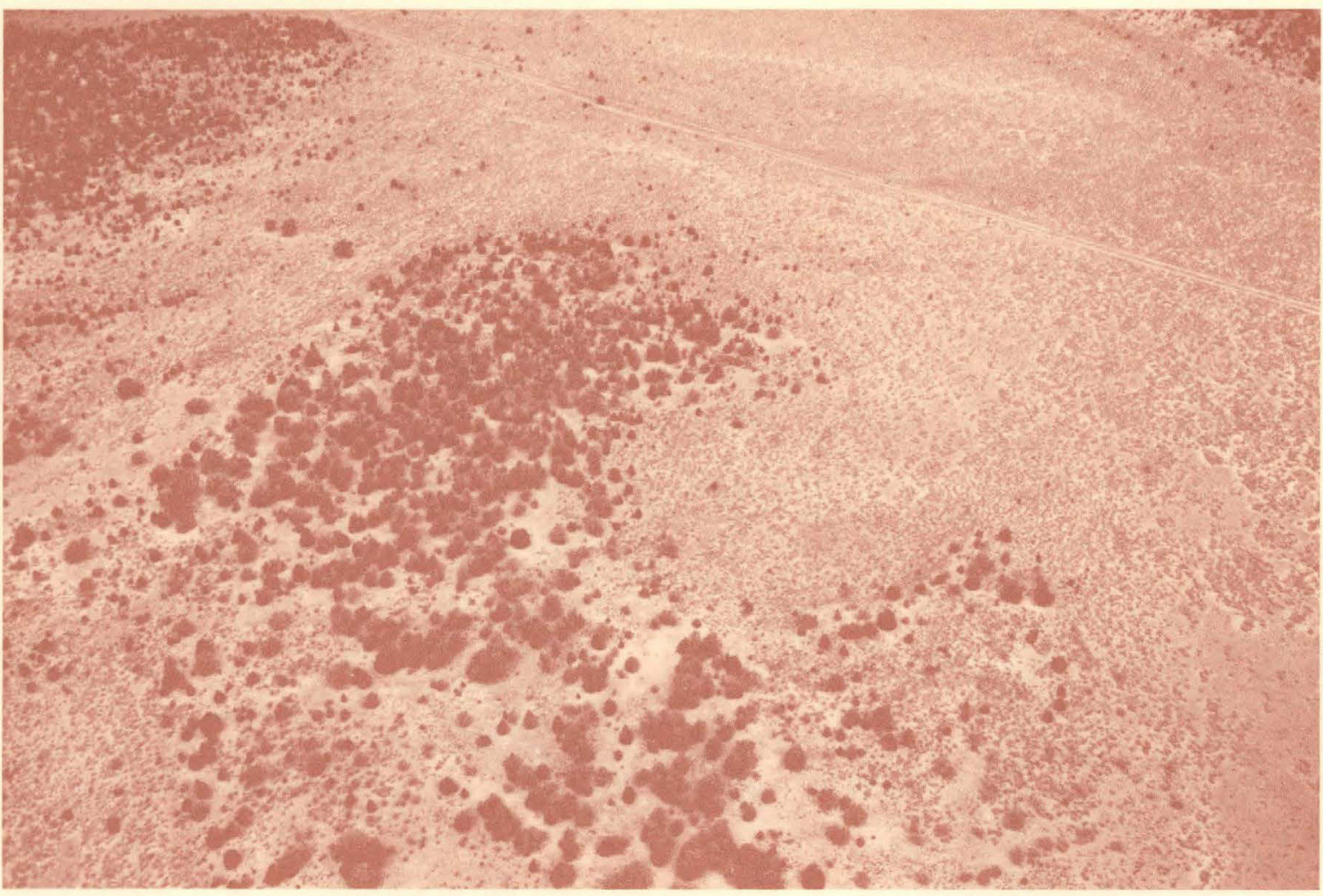


Aerial photograph on cover shows typical surface expression of breccia pipe in the National Tank area, as well as local terrain and vegetation. Hualapai Indian Reservation, Arizona. 
Chapter B

\section{The Potential of Breccia Pipes in the National Tank Area, Hualapai Indian Reservation, Arizona}

\section{BY KAREN J. WENRICH, GEORGE H. BILLINGSLEY, and BRADLEY S. VAN GOSEN}

This research was funded by the Bureau of Indian Affairs in cooperation with the Hualapai Indian Tribe

U.S. GEOLOGICAL SURVEY BULLETIN 1683-B

BRECCIA PIPES IN NORTHERN ARIZONA 
DEPARTMENT OF THE INTERIOR

MANUEL LUJAN, JR., Secretary

U.S. GEOLOGICAL SURVEY

Dallas L. Peck, Director

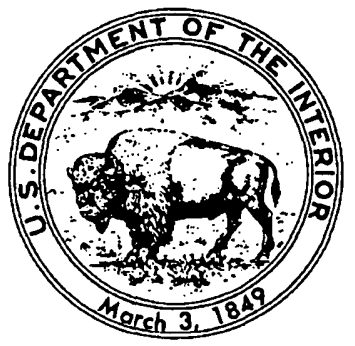

Any use of trade, product, or firm names in this report is for descriptive purposes only and does not imply endorsement by the U.S. Geological Survey.

UNITED STATES GOVERNMENT PRINTING OFFICE: 1989

For sale by the

Books and Open-File Reports Section

U.S. Geological Survey

Federal Center

Box 25425

Denver, CO 80225

Llbrary of Congress Cataloging-in-Publication Data

Wenrich, Karen J.

The potential of breccia pipes in the National Tank Area, Hualapai Indian Reservation, Arizona.

(Breccia pipes in northern Arizona;ch. B) (U.S. Geological Survey bulletin ; 1683-B)

Bibliography: $p$.

Supt. of Docs. no.: 1 19.3:1683-B

1. Breccia-Arizona-Mohave County. 2. Breccia-Arizona-Coconino County. I. Billingsley, George H. II. Van Gosen, B. S. (Bradley S.),

1960-. III. Title. IV. Series. V. Series: U.S. Geological Survey bulletin ; 1683-B.

QE75.B9

[QE471.15.B7]

no. $1683-B$

557.3 s [552'.5]

$88-600344$ 


\title{
CONTENTS
}

\author{
Abstract B1 \\ Introduction $\mathbf{B 1}$ \\ Acknowledgments B2 \\ Breccia pipes of northern Arizona $\mathbf{B 3}$ \\ Pipes on the Hualapai Indian Reservation B6 \\ The National Tank area B7 \\ Mapping of collapse features in the National Tank area $\quad$ B7 \\ Description of specific collapse features in the National Tank area $\quad$ B12 \\ Conclusions $\mathbf{B 3 2}$ \\ References cited $\quad$ B33

\section{FIGURES}

1. Index map of northern Arizona showing the location of plateaus, Hualapai Indian Reservation, breccia pipes developed into mines, and the San Francisco volcanic field B2

2. Stratigraphic column showing rock units that host breccia pipes in the Grand Canyon region of Arizona B3

3. Map of the Hualapai Indian Reservation showing confirmed and suspected breccia pipes mapped in the National Tank area between 1982 and 1986 B4

4. Geologic map of the National Tank area showing collapse features B8

5-11. Photographs:

5. Collapse feature $525 \quad$ B12

6. Collapse feature $531 \quad$ B13

7. Collapse feature $534 \quad$ B14

8. Collapse feature $537 \quad$ B15

9. Collapse feature $538 \quad$ B16

10. Collapse feature $539 \quad$ B17

11. Collapse feature 569 B18

12. Graphs of ground magnetometer traverse over collapse feature $569 \quad$ B19

13. Photographs of collapse feature $570 \quad$ B20

14. Photographs of collapse feature 571 B21

15. Graphs of soil sampling survey results from collapse feature $571 \quad$ B24

16-26. Photographs:

16. Collapse feature $572 \quad$ B25

17. Collapse feature $573 \quad$ B26

18. Collapse feature $574 \quad$ B27

19. Sink Tank (collapse feature 575) B28

20. Collapse feature $576 \quad$ B29

21. Collapse feature $998 \quad$ B29

22. Collapse features 1107 and $1108 \quad$ B30

23. Collapse feature $1114 \quad \mathrm{B30}$

24. Collapse feature $1115 \quad$ B31

25. Collapse feature $1116 \quad$ B31

26. Collapse feature $1119 \quad \mathbf{B 3 2}$ 
TABLES

1. Collapse features mapped in the National Tank area B10

2. Chemical analyses of soil samples collected from collapse feature $\mathbf{5 7 1}$ 


\title{
The Potential of Breccia Pipes in the National Tank Area, Hualapai Indian Reservation, Arizona
}

\author{
By Karen J. Wenrich, George H. Billingsley, and \\ Bradley S. Van Gosen
}

\section{Abstract}

The Hualapai Indian Reservation lies on the southwestern corner of the Colorado Plateau in northern Arizona. Thousands of solution-collapse breccia pipes crop out in the canyons and on the plateaus of northern Arizona. The pipes originated in the Mississippian Redwall Limestone and stoped their way upward through the upper Paleozoic strata, locally extending into the Triassic Moenkopi and Chinle Formations. The occurrence of high-grade $U$ ore, associated with potential byproduct concentrations of $\mathrm{Ag}$, $\mathrm{Pb}, \mathrm{Zn}, \mathrm{Cu}, \mathrm{Co}$, and $\mathrm{Ni}$ in some of these pipes, has stimulated exploration and mining activity in northern Arizona despite the depressed market for most of these elements.

More than 900 confirmed and suspected breccia pipes were mapped on the Hualapai Reservation between 1982 and 1986. Although breccia pipes are easily recognized within canyons where their vertical dimension is exposed, large expanses of northern Arizona are composed of undissected high plateaus. Recognition of pipes in these areas is particularly important because mining access to the plateaus is significantly better than to the canyons and the greater volume of overlying sandstones provided more host rock for ore precipitation by mineralizing fluids. Shallow structural basins on these plateaus are commonly the surface expression of the upper part of breccia pipes.

The National Tank area on the Hualapai Indian Reservation, Arizona, was selected to demonstrate the high density of collapse features (suspected to be breccia pipes) that lie on these plateaus. Because most of the area is soil-covered and rock outcrops are few, soil geochemical, helium-soil gas, Bacillus cereus, and geophysical surveys were used to evaluate the potential that mapped collapse features are breccia pipes rather than more shallow-rooted solution features. Circular erosion patterns and vegetation changes are the only visible signs of collapse structures in the National Tank area. Twenty-five collapse features were mapped and described within this area; of these, thre日-534,

Manuscript approved for publication, February 14, 1989.
569 , and 570-appear to have the greatest potential to be breccia pipes.

\section{INTRODUCTION}

The Colorado Plateau of northern Arizona is host to thousands of breccia pipes, many of which were mineralized by $\mathrm{Cu}-, \mathrm{U}-, \mathrm{Ag}-, \mathrm{Pb}-, \mathrm{Zn}-, \mathrm{Co}-$, and Nibearing fluids. Despite the depressed uranium market, the level of exploration activity for mineralized breccia pipes in north-central and northwestern Arizona has remained high.

The Hualapai Tribal Council requested in 1985 that the U.S. Geological Survey select two areas of potentially mineralized breccia pipes on the Hualapai Reservation (fig. 1) that the tribe could consider leasing to the mining community. The selection was based on maximum number of collapse features per area and distance from residential communities. The two areas selected represent, in general, two very different exposures of breccia pipes: (1) In the Mohawk Canyon area, mineralized rock is commonly exposed in cliff faces and along canyon bottoms in all formations from the Permian Kaibab Limestone to the Mississippian Redwall Limestone (fig. 2). Much of this area is not easily accessible and cannot be reached by motor vehicle. (2) In the National Tank area, mineralized rock is not exposed; in fact, little rock of any sort is exposed, and most of the area is soil-covered. Consequently, mapping is restricted to recognition of collapse features at the surface, which may or may not be mineralized at depth. However, most of the area is readily accessible by road. The National Tank area is the focus of this report; the Mohawk Canyon area is discussed in a separate report (Wenrich, Billingsley, and Van Gosen, 1990). 


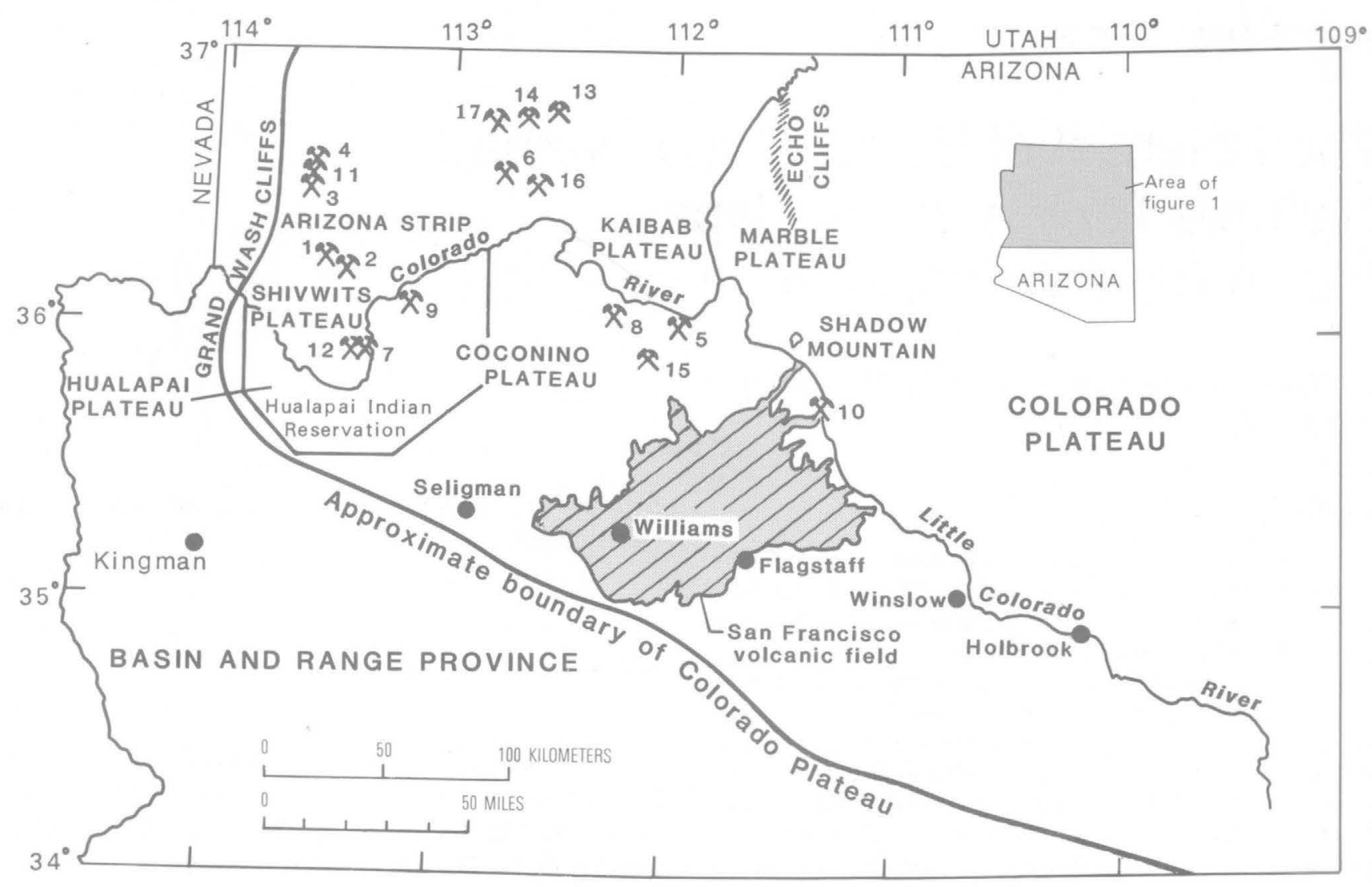

Figure 1. Index map of northern Arizona showing the location of plateaus, Hualapai Indian Reservation, breccia pipes developed, or being developed into mines, and the San Francisco volcanic field (patterned area) that buries terrane with high potential for breccia pipes. Numbers refer to the following mines:
1. Copper House
6. Hack Canyon
11. Savanic
16. Pinenut
2. Copper Mountain
7. Old Bonnie
12. Snyder
17. Hermit
3. Cunningham
8. Orphan
13. Pigeon
9. Ridenour
14. Kanab North
5. Grandview
10. Riverview
15. Canyon

More than 900 confirmed and suspected breccia pipes were mapped on the Hualapai Reservation between 1982 and 1986 (fig. 3). This density of collapse features is not unique to the Hualapai Reservation, the western edge of this pipe-rich region in Arizona, but extends eastward where a similar concentration of pipes had been mapped earlier on the Marble Plateau (Verbeek and Wenrich-Verbeek, 1980; Wenrich-Verbeek and Verbeek, 1980; Sutphin and Wenrich, 1983; Sutphin, 1986). Thus, throughout the paper the terms solution collapse, structure, or feature are defined as those areas that apparently collapsed due to dissolution of any underlying rock, whereas the term breccia pipe refers specifically to dissolution of the Redwall Limestone, which resulted in stoping and brecciation of the overlying rock.

\section{Acknowledgments}

This project was funded by the U.S. Bureau of Indian Affairs in cooperation with the Hualapai Tribe. Much appreciation goes to Hoyt B. Sutphin who provided mapping assistance in the early stages of this project. His continued assistance, enthusiasm, and exchange of ideas contributed to many of our conclusions. Joseph F. Mascarenas and Betsi Burmaster collected many of the soil samples over these collapse 
Thickness range,

in feet

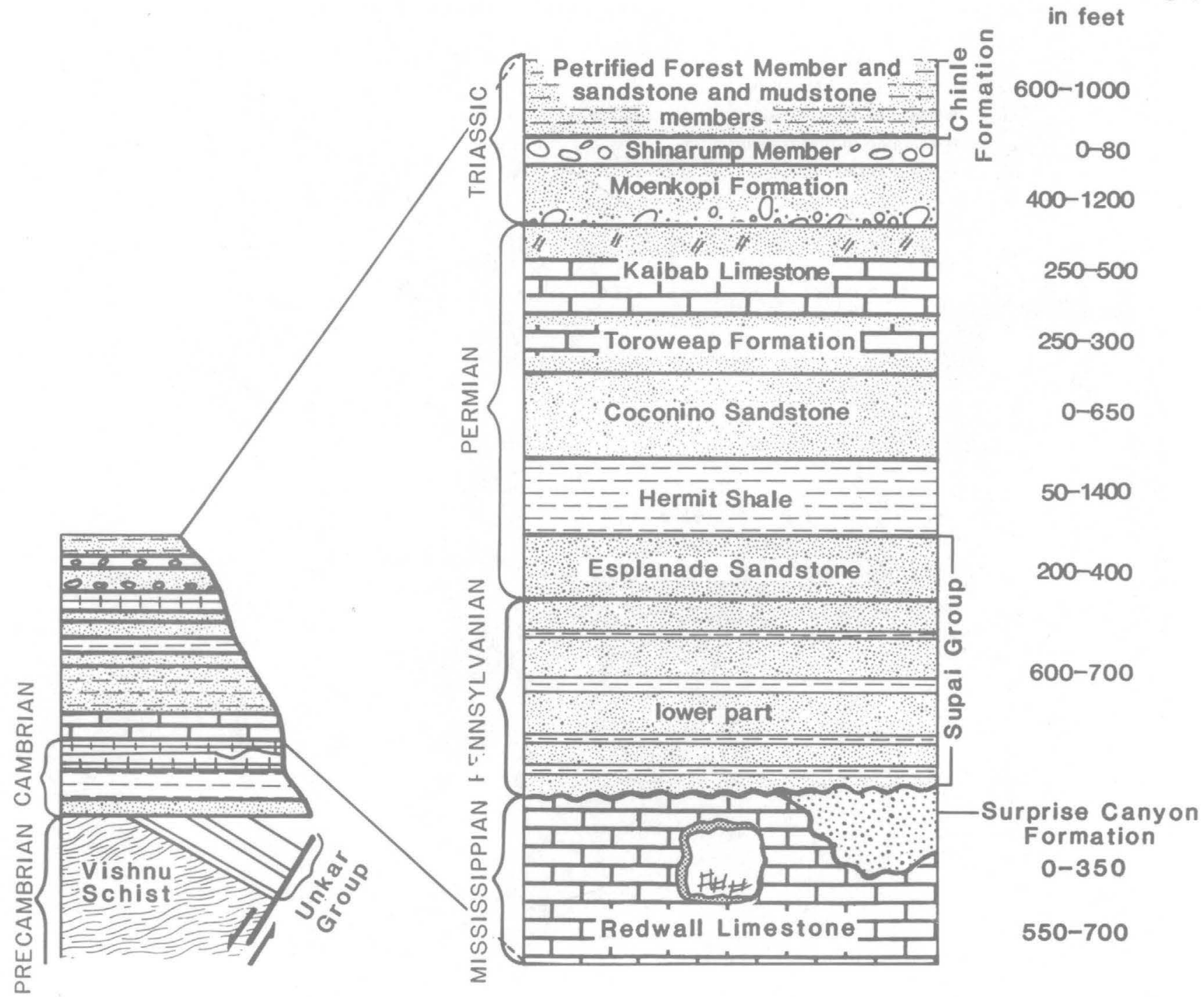

Figure 2. Stratigraphic column showing rock units that host breccia pipes in the Grand Canyon region of Arizona. The thickness shown for each unit is that characteristic of the area shown in figure 1.

features. Earl R. Verbeek critically reviewed the manuscript and his suggestions were greatly appreciated and incorporated.

\section{BRECCIA PIPES OF NORTHERN ARIZONA}

The breccia pipes of northern Arizona differ from classic breccia pipes in that there are no volcanic rock associations in time or space; instead, they result from solution collapse within the Redwall Limestone and stoping of the overlying strata. Dissolution of the Redwall Limestone created caverns into which blocks of overlying strata collapsed, leading to gradual upward stoping of a rubble-filled, approximately $300 \mathrm{ft}(100 \mathrm{~m})$ in diameter, pipe-like structure. The pipes and associated mineralized rock transgress formational boundaries from the Mississippian Redwall Limestone through the Triassic Chinle Formation (fig. 2) - a vertical distance on the order of $4,000 \mathrm{ft}(1,300 \mathrm{~m})$. No pipes have been observed in rock below the base of the Whitmore Wash Member of the Redwall Limestone during this study, nor during studies by Huntoon and others $(1981,1982)$ and Billingsley and 


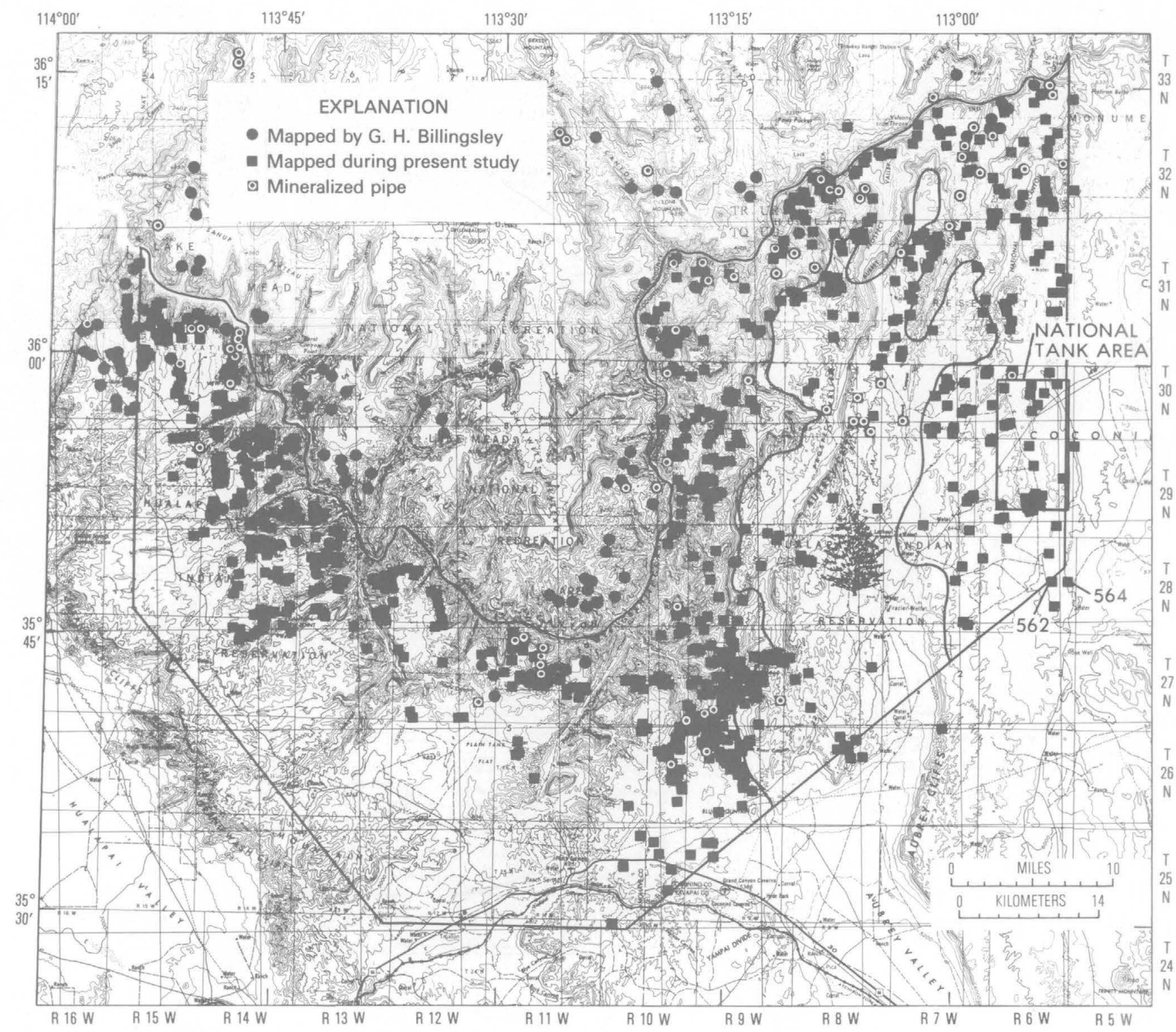

Figure 3. The National Tank area is located on the eastern edge of the Hualapai Indian Reservation (outlined by rectangle). More than 900 confirmed and suspected breccia pipes were mapped on the Hualapai Reservation between 1982 and 1986. The western side has sparse vegetation, which is reflected in the greater density of identified collapses. This area provides an example of the solution collapse density when detailed mapping is completed. Area outlined in black (shown with a tree symbol in the center) on east side of map is densely tree covered, preventing recognition of most pipes.

Huntoon (1983). The stoping produced extensive brecciation of the rock within the steep walls of the pipe. At no level in any pipe have breccia clasts been observed from deeper beds; all material has been dropped into the pipe from stratigraphically higher units. As a result of collapse, brecciated rock within each pipe abuts generally well-stratified, undeformed sedimentary rock; the plane demarking this contact is obviously one along which the breccia slid downward and is, therefore, by definition, a fracture (see fig. 1b, Wenrich, 1985). This nearly vertical fracture is referred to here as the ring fracture.

The breccia pipes of northern Arizona extend to the Utah State line and south to the Mogollon Rim (the southern margin of the Colorado Plateau). They are abundant from the edge of the Grand Wash Cliffs (the western margin of the Colorado Plateau) across theHua- 
lapai Indian Reservation, through Coconino National Forest to the Marble Plateau of the Navajo Reservation (fig. 1). No pipes are known east of the Echo Cliffs. Perhaps the area best known for breccia pipes is the Arizona Strip extending from the Grand Canyon northward to Utah; the flurry of mining ventures during the past 7 years, including the Hack Canyon mines, Kanab North mine, and the Pigeon mine, has brought recent prominence to this region. Pipes undoubtedly also exist along the southern margin of the Colorado Plateau, but for the most part are buried beneath the lavas of the San Francisco volcanic field.

Mining activity in breccia pipes of the Grand Canyon region began during the 19th century; at that time essentially all ore produced was copper. It was not until 1951 when high gamma radioactivity was discovered on the Orphan mine dump (Chenoweth, 1986) that these mines were first recognized to contain uraniummineralized rock. Metals produced from one or more pipes during the past century include $\mathrm{Cu}, \mathrm{U}, \mathrm{Ag}, \mathrm{Au}, \mathrm{Pb}$, and $\mathrm{Zn}$ (Foord and others, 1978). Uranium ore from mines within these pipes is exceptionally high grade; 4.26 million $\mathrm{lbs} \mathrm{U}_{3} \mathrm{O}_{8}$, composed primarily of uraninite, was removed from the Orphan mine averaging 0.43 percent $\mathrm{U}_{3} \mathrm{O}_{8}$ (Chenoweth, 1986). Other mined breccia pipes have, or had, grades and tonnages similar to those of the Orphan mine. All active mines are presently being operated essentially for their uranium content, although silver could be extracted as a byproduct in some if an appropriate mill were available; the Orphan mine produced 107,000 ounces of $\mathrm{Ag}$ from the copper ore from 1962 through 1969 at a grade of $0.35-0.45 \mathrm{oz} /$ ton (ounces per ton; 11-14 ppm) (Chenoweth, 1986). Analyses of uranium-mineralized rock from breccia pipes throughout the Grand Canyon region routinely yield silver values of 10-100 ppm; some samples contain as much as 1,150 ppm (35 oz/ton) (Wenrich, 1985).

Dissolution of the Redwall Limestone began during the Late Mississippian, creating an extensive karst terrain. The breccia pipes include strata up through the Triassic Chinle Formation, but no pipes have been observed to extend into younger rocks. Thus, it is probably safe to assume that formation of breccia pipes by stoping began at least by Early Pennsylvanian time and continued until, or at least was reactivated, in the Triassic. A minimum age of 141 m.y. (latest Jurassic-earliest Cretaceous) was determined for uraninite from the Orphan mine by U-Pb dating (Gornitz and Kerr, 1970). Preliminary $\mathrm{U}-\mathrm{Pb}$ isotope data for uraninite from the Hack breccia pipes suggest a main period of mineralization of roughly 200 m.y. ago (late Triassicearly Jurassic) (Ludwig and others, 1986). The 200 m.y. age is in better agreement with the break in observed mineralized rock between the Triassic and Jurassic; that is, there are known pipes with Triassic strata but none with Jurassic or younger rock.

Geological and geochemical controls on the mineralization of these breccia pipes are poorly understood at present. A more detailed discussion of the mineralogy and geochemistry of breccia pipes in northern Arizona is provided by Wenrich and Sutphin (1989). There is little doubt that pipe locations are in part structurally controlled, particularly on the Marble Plateau (Sutphin and others, 1983; Sutphin and Wenrich, 1983), and that the pipes occur in clusters. Clustering of mineralized pipes is especially obvious in the Hack Canyon area, where the Hack I, II, III, and old Hack Canyon mines (four separate pipes) all occur within one square mile $\left(2.5 \mathrm{~km}^{2}\right)$ of each other. This proximity implies a hydrologic connection between multiple pipes and suggests that the mineralizing fluids circulated through all four pipes at the same time. Such a connecting system can be observed in a Redwall cave, with over a mile of passages, located on the west side of Peach Springs Canyon. Here the bottoms of four breccia pipes, aligned in a straight row and equally spaced, form broad chimneys in the ceiling of one passage (Wenrich and Sutphin, 1989)

An extensive suite of elements is anomalously concentrated in mineralized rock within breccia pipes throughout northern Arizona. This association is remarkably consistent from pipe to pipe: $\mathrm{Ag}, \mathrm{As}, \mathrm{Ba}, \mathrm{Cd}$, $\mathrm{Co}, \mathrm{Cs}, \mathrm{Cu}, \mathrm{Hg}, \mathrm{Mo}, \mathrm{Ni}, \mathrm{Pb}, \mathrm{Sb}, \mathrm{Se}, \mathrm{Sr}, \mathrm{V}, \mathrm{Zn}$, and, less commonly, the rare-earth elements. In addition to this suite of elements, a black glassy pyrobitumen is found with the brecciated rock in many mineralized pipes, including the Mohawk Canyon pipe (Wenrich and others, 1988). This material appears to have solidified after such associated minerals as pyrite and barite. Samples from the breccia pipes containing pyrite and pyrobitumen are visually indistinguishable from samples collected from Mississippi Valley-type deposits (Wenrich and others, 1988).

Primary and secondary fluid inclusions in sphalerite, dolomite, quartz, calcite, and anhydrite from several pipes scattered across northern Arizona yield filling temperatures that range from $86^{\circ}$ to $222^{\circ} \mathrm{C}$. Salinities of fluids included in sphalerite are consistently higher than 10 weight percent $\mathrm{NaCl}$ equivalent. Sphalerite (secondary inclusions) filling temperatures range from $86^{\circ}$ to $173^{\circ} \mathrm{C}$; dolomite (primary inclusions) from $130^{\circ}$ to $145{ }^{\circ} \mathrm{C}$; quartz (secondary inclusions within the silicified spire of the Blue Mountain pipe) from $275^{\circ}$ to $305^{\circ} \mathrm{C}$; and anhydrite (primary inclusions) from $187^{\circ}$ to 
$222{ }^{\circ} \mathrm{C}$. These fluid-inclusion filling temperatures and salinities are also in agreement with those found in Mississippi Valley-type deposits, suggesting a similar genesis for pipe minerals such as sphalerite and galena, and the $\mathrm{Co}$ and $\mathrm{Ni}$ phases. Nevertheless, the absence of known uranium occurrences in Mississippi Valley-type deposits (D.L. Leach, oral commun., 1985) contrasts sharply with the pipe mineralogy. This does not preclude the base-metal breccia pipe assemblage from having a similar genesis to Mississippi Valley-type deposits, as the uraninite is paragenetically later than the base metal minerals in the breccia pipes and may well have precipitated from later mineralizing fluids. These data suggest that the base metals were probably precipitated from a moderately low-temperature brine solution, which exceeded the temperature that would be expected from the normal geothermal gradient on the Colorado Plateau with a burial depth of 3,000-5,000 ft (900-1,500 $\mathrm{m})$. The quartz may well have crystallized from a latestage (later than all ore precipitation) silicification event, which only occurs in some pipes, such as the West collapse on the Marble Plateau and the Blue Mountain pipe.

\section{Pipes On The Hualapai Indian Reservation}

The Hualapai Indian Reservation is situated in the southwestern corner of the Colorado Plateau (fig. 1). The western half of the reservation, located on the Hualapai Plateau and bounded on the west by the Grand Wash Cliffs, is capped by the Redwall Limestone. No more than $500 \mathrm{ft}(175 \mathrm{~m})$ of possible rock thicknesss is available to host an orebody and little of it is sandstone. Most is limestone, which generally is an unfavorable host for uranium mineralization; thus, the Hualapai Plateau is not considered favorable for economic breccia pipes, and has been eliminated for potential drilling targets. In contrast, the eastern part of the reservation occupies the western edge of the Coconino Plateau which is capped, for the most part, by the Harrisburg Gypsiferous Member of the Kaibab Limestone. This thick stratigraphic column of rock, in excess of $2,500 \mathrm{ft}(800 \mathrm{~m})$, provides ample host rock for potential mineral deposits. In addition, this plateau surface lies at the same horizon as that above most breccia pipes hosting orebodies in northern Arizona.

Mapping collapse features as manifestations of breccia pipes on high plateaus (such as the Coconino, Kaibab, and Marble Plateaus) capped by the Kaibab Limestone or younger units is complicated both by karst development in the Kaibab Limestone and solution collapses formed where gypsum is dissolved from the underlying Toroweap Formation, or from the Harrisburg Gypsiferous Member of the Kaibab Limestone. It is generally assumed that those collapse features resembling ordinary sink holes-with vertical walls, no tilted beds, and a bottom covered by uncemented rubble-are recent karst landforms. In contrast, collapse features with inward-tilted beds and alteration appear to be favorable indicators of concealed breccia pipes. Unfortunately, drilling results indicate that not all collapses possessing these favorable characteristics have breccia pipes beneath them, suggesting that geochemical and geophysical exploration techniques should be used before drilling.

Although the dissolution of gypsum in the Toroweap Formation and of both limestone and gypsum in the Kaibab Limestone is a complicating factor, the process apparently enhances the surface expression of those features that are, indeed, breccia pipes. Most of the lower plateau surfaces, most notably the Esplanade surface (at the top of the Esplanade Sandstone, fig. 2), do not have the density of features exposed that the Kaibab-, Moenkopi-, and Chinle-capped plateaus have. Initially this greater density of features might appear to suggest that most features on these latter plateaus are merely sinkholes within the Kaibab and Toroweap. To the contrary, apparently the presence of a breccia pipe increases the movement of fluids not only within the pipe itself but also laterally in various formations adjacent to the pipe. The effects of enhanced circulation can be seen in the core from the Mohawk Canyon pipe (Wenrich and others, 1988); here the gypsiferous Woods Ranch Member of the Toroweap Formation has been almost entirely removed from the brecciated column. Dissolution of the upper soluble units in the vicinity of pipes may well account for the discrepancy in size between the pipes and the much larger collapse features that are commonly mapped above them. All known orebodies range from 100 to $300 \mathrm{ft}$ (most commonly about $250 \mathrm{ft}$ ) in diameter, whereas many of the collapse features on plateau surfaces are as much as $1,300 \mathrm{ft}$ across (most notable is the Pigeon pipe, fig. 1). The largest known collapse-Shadow Mountain collapse on the Marble Plateau - is more than one mile in diameter, and is located within a mile of Shadow Mountain, a Tertiary basaltic cinder cone. The actual Shadow Mountain breccia pipe may be no more than the average $250 \mathrm{ft}$ in diameter, but the Tertiary solutions associated with the volcanism must have caused extensive recent dissolution of some of the formations underlying the pipe (such as large-scale dissolution of the Redwall or Muav 
Limestones, as there is no soluble rock within the Toroweap and Kaibab on the Marble Plateau). Thus, locating the actual breccia pipe, and perhaps an orebody, will be more difficult at Shadow Mountain than in a small collapse, such as the Mohawk Canyon pipe. Exploration for mineralized breccia pipes may be more successful on the upper plateaus where dissolution has enlarged the collapse within the upper Paleozoic units, in some places more than ten times the pipe size on lower plateaus, because the lower plateaus are capped mostly by insoluble rock such as the Esplanade Sandstone. This increase in solution collapse beneath the upper plateaus, which are capped by soluble Late Permian and younger rocks, emphasizes the importance of mapping all solution features in these areas.

Many exploration criteria for detecting mineralized breccia pipes were developed during mapping. Mapping on the Hualapai Reservation began on 1:24,000 color aerial photographs, and was then field checked. Many pipes exposed along cliff faces are not recognizable on vertical aerial photographs and are best spotted from a helicopter.

The following exploration criteria are considered favorable indicators of mineralized breccia pipes:

1. Concentrically inward-dipping beds.

2. A circular topographic pattern. This pattern is commonly expressed as a topographically high rim around a central depression.

3. Anomalous radioactivity; 2.5 times background or higher is considered anomalous in this report.

4. Goethite pseudomorphs and molds of pyrite.

5. Colloform celadonite-stained chalcedony.

6. Copper mineralization expressed on surface exposure as the supergene minerals malachite, azurite, brochantite, and chrysocolla.

7. Breccia, other than intraformational breccias.

8. Anomalous concentrations in surface samples of such trace elements as $\mathrm{Ag}, \mathrm{As}, \mathrm{Cd}, \mathrm{Co}, \mathrm{Cu}$, $\mathrm{Mo}, \mathrm{Ni}, \mathrm{Pb}, \mathrm{Se}, \mathrm{V}$, and $\mathrm{Zn}$.

9. A circular vegetation or color pattern.

To verify that a collapse feature mapped from the air is a breccia pipe, these criteria must be checked in the field. Few pipes exhibit all these criteria on surface exposure, but the more that are present, the greater the certainty that the feature is a breccia pipe as opposed to a collapse structure.

Although breccia pipes are easily recognized within canyons where they are exposed in cross section, large expanses of northern Arizona are composed of undissected high plateaus. Recognition of pipes in these areas is particularly important because ease of access would promote mining that would be difficult or uneconomic in the canyons. In addition, pipes exposed in canyon walls have commonly lost much of their rock, including mineralized rock, to erosion and perhaps their metals to leaching. Shallow structural basins on the adjacent plateaus are probably surface expressions of the upper part of breccia pipes. This assumption is supported by the occasional exposure of a breccia pipe in a canyon wall directly beneath a shallow structural basin on the plateau surface (Wenrich, 1985, fig. 5). Because the ring fracture, which delineates the actual pipe, is well exposed in less than half the mapped collapse features, and in order to be consistent throughout the mapped area, the boundaries of the breccia pipes were mapped as the outermost extent of inward-dipping beds. It should be emphasized that this area mapped as a solution collapse can be as much as five times the size of the actual breccia pipe, due to dissolution of the Toroweap and Kaibab adjacent to the pipe.

\section{THE NATIONAL TANK AREA}

The National Tank area (fig. 3) lies within the National Tank 71/2-minute topographic quadrangle, on the Coconino Plateau along the eastern edge of the Hualapai Reservation. The area is capped almost entirely by the Harrisburg Gypsiferous Member of the Kaibab Limestone; the Fossil Mountain Member is exposed only in a small canyon in the northwest corner (fig. 4). The area is essentially undissected. Relative to much of the Hualapai Reservation, this area has significant vegetation cover, primarily rangeland grasses, pinyon pine, and juniper.

\section{Mapping of Collapse Features in the National Tank Area}

Most of the National Tank area is soil-covered with little rock outcrop, which makes use of any of the first eight exploration criteria difficult. Circular topographic patterns and vegetation changes are the only observable features that permit mapping of collapse structures in the area. Because of the extremely limited rock outcrop, it is impossible to determine from the surface whether these are breccia pipes that extend downward into the Redwall Limestone or are merely collapse features that may bottom in the Kaibab Limestone or Toroweap Formation. Nevertheless, this area is of potential economic importance because (l) all features are readily 


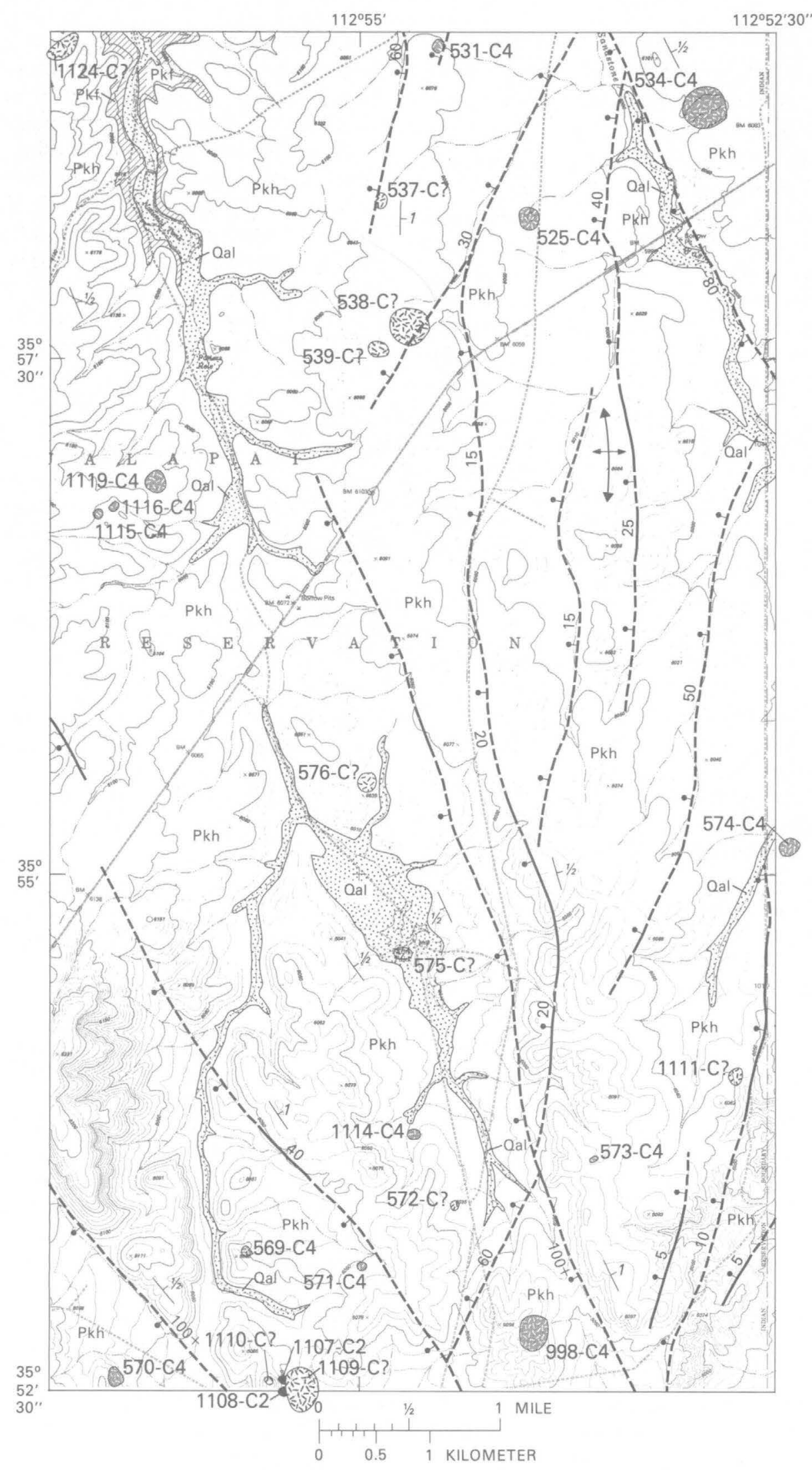

Figure 4 (above and facing page). Geologic map of the National Tank area showing collapse features. 
Qal

Pkh

$\mathrm{Pkf}$

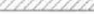

ALLUVIUM (HOLOCENE)--

Silt, sand, and gravel. Not all alluvium is shown

KAIBAB LIMESTONE (LOWER PERMIAN)--

Harrisburg Gypsiferous Member--Slope- and ledge-forming gray and pale-red

shales and gypsiferous siltstone interbedded with gray, ledge-forming

limestone and dolomitic sandstone. Includes in lower part intraforma-

tional breccia beds of ripup chert clasts recemented with chert

KAIBAB LIMESTONE (LOWER PERMIAN)--

Fossil Mountain Member-- A yellowish-gray fossiliferous cherty limestone and sandy limestone, forms cliff

SYMBOLS

\section{CONTACT BETWEEN MAP UNITS}

FAULT--

Dashed where position uncertain; dotted where concealed; bar and ball on downthrown side; 20 indicates approximate stratigraphic offset in feet

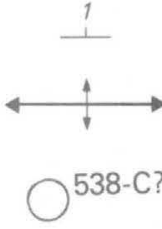

STRIKE AND DIP OF BEDS

aXIAL tRACE OF ANTICLINE

COLLAPSE FEATURES--

Collapse feature number used in text to identify each collapse

\section{COLLAPSE FEATURE CLASSIFICATION}

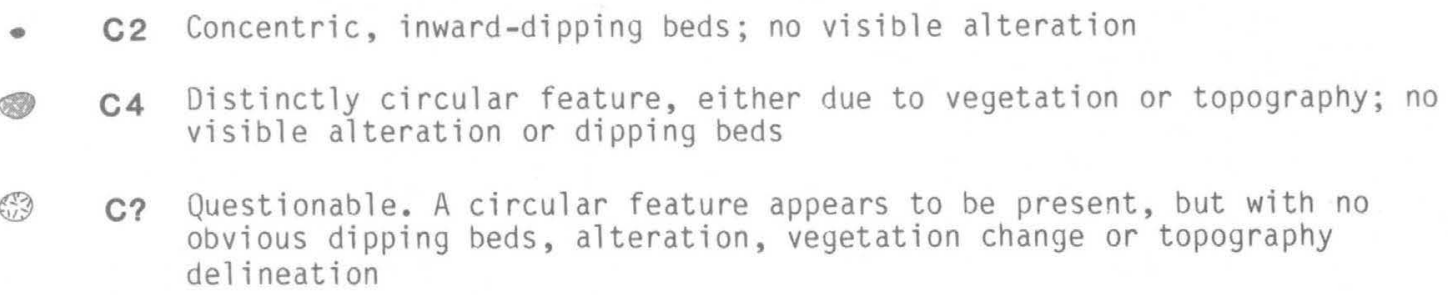

accessible by four-wheel drive vehicle (the paved Supai highway passes through the middle of the area), and (2) the entire $2,500 \mathrm{ft}(800 \mathrm{~m})$ of stratigraphic sequence are present, permitting maximum preservation of any orebody that might be present.

The collapse features were originally mapped from 1:24,000 color aerial photographs. In the National Tank area, 25 features (fig. 4) have been mapped, field checked, verified as collapse features, and are considered likely to be breccia pipes. Many of these features appear circular from low-altitude aerial photographs and from directly overhead in a helicopter, but once on the ground, the circular nature of the feature is difficult to recognize. In most cases this circular nature is merely a circular color patch, although a few features do appear to have inward-tilting beds. Unfortunately, recognition of such features depends almost entirely on the vegetation, which is uniformly brown, except during summer when the centers of the collapse structures tend to be greener than surrounding areas. The greener centers are due in some cases to the negative topographic expression of some features, so that water drains into them. In other cases it is probably due to the highly fractured rock, which could permit enhanced water movement into the overlying soil. In any event, mapping in these areas of high plateaus where rock outcrops are few should be restricted to the summer months during the monsoon season when vegetation within the collapse structures are green. 
Table 1. Collapse features mapped in the National Tank area, Hualapai Indian Reservation, Arizona. The surface expression of all these collapse features is in the Harrisburg Gypsiferous Member of the Kaibab Limestone

\begin{tabular}{|c|c|c|c|c|c|}
\hline $\begin{array}{l}\text { Feature } \\
\text { No. }\end{array}$ & $\begin{array}{l}71 / 2 \text {-minute } \\
\text { topographic } \\
\text { quadrangle }\end{array}$ & Location & $\begin{array}{l}\text { Lat, } \\
\text { Long }\end{array}$ & $\begin{array}{l}\text { Collapse } \\
\text { category }\end{array}$ & Comments \\
\hline 525 & National Tank & $\begin{array}{l}\text { Sec. } 23 \text {, } \\
\text { T. } 30 \text { N., R. } 6 \text { W. }\end{array}$ & $\begin{array}{l}35^{\circ} 58^{\circ} 11^{\prime \prime} \\
112^{\circ} 53^{\circ} 58^{\prime \prime}\end{array}$ & $\mathrm{C} 4$ & $\begin{array}{l}\text { Circular depression; no outcrop; reddish-soll and vegetation in a } \\
\text { complete circle (fig. } 5 \text { ). }\end{array}$ \\
\hline 531 & National Tank & $\begin{array}{l}\text { Sec. } 15, \\
\text { T. } 30 \text { N., R. } 6 \text { W. }\end{array}$ & $\begin{array}{l}35^{\circ} 59^{\circ} 00^{\prime \prime} \\
112^{\circ} 54^{\circ} 32^{\prime \prime}\end{array}$ & $\mathrm{C4}$ & $\begin{array}{l}\text { Circular depression of sagebrush } 80 \text { percent surrounded by a tree- } \\
\text { covered rim and reddish soll (fig. } 6) \text {. }\end{array}$ \\
\hline 534 & National Tank & $\begin{array}{l}\text { Sec. } 13, \\
\text { T. } 30 \text { N., R. } 6 \text { W. }\end{array}$ & $\begin{array}{l}35^{\circ} 58^{\circ} 43^{\prime \prime} \\
112^{\circ} 52^{\circ} 54^{\prime \prime}\end{array}$ & $\mathrm{C} 4$ & Circular depression. Outcrop on north side dips Inward (fig. 7 ). \\
\hline 537 & National Tank & $\begin{array}{l}\text { Sec. } 22, \\
\text { T. } 30 \text { N., R. } 6 \text { W. }\end{array}$ & $\begin{array}{l}35^{\circ} 58^{-} 16^{\prime \prime} \\
112^{\circ} 54^{\circ} 53^{\prime \prime}\end{array}$ & C? & $\begin{array}{l}\text { S1ight bowl-shaped depression; no outcrop; soll and vegetation } \\
\text { change (fig. 8). }\end{array}$ \\
\hline 538 & National Tank & $\begin{array}{l}\text { Sec. } 27 \\
\text { T. } 30 \text { N., R. } 6 \text { W. }\end{array}$ & $\begin{array}{l}35^{\circ} 57^{\circ} 40^{\prime \prime} \\
112^{\circ} 54^{\circ} 42^{\prime \prime}\end{array}$ & $\mathrm{c} ?$ & Very questionable; reddish soll patch (fig. 9). \\
\hline 539 & NatIonal Tank & $\begin{array}{l}\text { Sec. } 27, \\
\text { T. } 30 \text { N., R. } 6 \text { W. }\end{array}$ & $\begin{array}{l}35^{\circ} 57^{\circ} 32^{\prime \prime} \\
112^{\circ} 54^{\circ} 51^{\prime \prime}\end{array}$ & $\mathrm{C} ?$ & $\begin{array}{l}\text { C1rcular pattern of sagebrush; slight bowl-shaped depression } \\
\text { (fig. 10). }\end{array}$ \\
\hline 569 & National Tank & $\begin{array}{l}\text { Sec. } 21, \\
\text { T. } 29 \text { N., R. } 6 \text { W. }\end{array}$ & $\begin{array}{l}35^{\circ} 53^{\circ} 08^{\prime \prime} \\
112^{\circ} 55^{\circ} 40^{\prime \prime}\end{array}$ & $\mathrm{C4}$ & $\begin{array}{l}\text { Oblong, closed reddish soll-covered depression, rimmed by hill } \\
\text { of Kaibab float (fig. } 11) \text {. }\end{array}$ \\
\hline 570 & Nat1onal Tank & $\begin{array}{l}\text { Sec. } 20 \text {, } \\
\text { T. } 29 \text { N., R. } 6 \text { W. }\end{array}$ & $\begin{array}{l}35^{\circ} 52^{-} 34^{\prime \prime} \\
112^{\circ} 56^{\circ} 29^{\prime \prime}\end{array}$ & $\mathrm{C4}$ & $\begin{array}{l}\text { Semicircular shape; reddish soll in center; ratsed, white soll- } \\
\text { covered rim (fig. 13). }\end{array}$ \\
\hline 571 & National Tank & $\begin{array}{l}\text { Sec. } 22 \text {, } \\
\text { T. } 29 \text { N., R. } 6 \text { w. }\end{array}$ & $\begin{array}{l}35^{\circ} 53^{\circ} 06^{\prime \prime} \\
112^{\circ} 54^{\circ} 28\end{array}$ & $\mathrm{C} 4$ & $\begin{array}{l}\text { Circular depression; darker soll and denser vegetation within } \\
\text { depression; surrounded by a rim of lighter-colored soil (fig. 14). }\end{array}$ \\
\hline 572 & National Tank & $\begin{array}{l}\text { Sec. } 22, \\
\text { T. } 29 \text { N., R. } 6 \text { W. }\end{array}$ & $\begin{array}{l}35^{\circ} 53^{\circ} 24^{\prime \prime} \\
112^{\circ} 54^{-} \\
26^{\prime \prime}\end{array}$ & C? & $\begin{array}{l}\text { C1rcular, falrly green patch of grass surrounded by sagebrush } \\
\text { (f1g. 16). }\end{array}$ \\
\hline 573 & National Tank & $\begin{array}{l}\text { Sec. } 14, \\
\text { T. } 29 \text { N., R. } 6 \text { W. }\end{array}$ & $\begin{array}{l}35^{\circ} 53^{\circ} 38^{\prime \prime} \\
112^{\circ} 53^{\circ} 36^{\prime \prime}\end{array}$ & $\mathrm{C} 4$ & Circular depression with grass patch Inside (fig. 17). \\
\hline 574 & Supal Camp & $\begin{array}{l}\text { Sec. } 12, \\
\text { T. } 29 \text { N., R. } 6 \text { W. }\end{array}$ & $\begin{array}{l}35^{\circ} 52^{-} 37^{\prime \prime} \\
112^{\circ} 52^{\circ} 25^{\prime \prime}\end{array}$ & $\mathrm{C} 4$ & $\begin{array}{l}\text { Large, reddish soll-covered center surrounded by circular to } \\
\text { elliptical hill with some trees (fig. 18). }\end{array}$ \\
\hline 575 & National Tank & $\begin{array}{l}\text { Sec. } 10 \\
\text { T. } 29 \text { N., R. } 6 \text { W. }\end{array}$ & $\begin{array}{l}35^{\circ} 54^{\circ} 07^{\prime \prime} \\
112^{\circ} 54^{\circ} 44^{\prime \prime}\end{array}$ & c? & Sink Tank; possibly a C2; outcrop has tilted beds (fig. 19). \\
\hline
\end{tabular}


$35^{\circ} 55^{\circ} 27^{\prime \prime}$

$35^{\circ} 52^{-} 47^{\prime \prime}$

c. 23

T. $29^{\circ}$ N., R. 6 W. $112^{\circ} 53^{\circ} 59^{\prime \prime}$

1108

National Tank Sec. 21

T. 29 N., R. 6 W.

$35^{\circ} 52^{-} 33^{\prime \prime}$

$35^{\circ} 52^{\prime} 28^{\prime \prime}$,

Sec. 28,

T. $29^{\circ}$ N., R. 6 W. $112^{\circ} 55^{\circ} 28^{\prime \prime}$

National Tank/ Sec. 21, 28 ,

Dike Tank

1110

1111

National Tank

T. 29

$35^{\circ} 52^{-} 30^{\prime \prime}$

$35^{\circ} 52^{-} 32^{\prime \prime}$,

c. 21 ,

T. 29 N., R. 6 W.

National Tank

Sec. 13

T. 29 N., R. 6 W.

$35^{\circ} 54^{\circ} 01^{\prime \prime}$

$112^{\circ} 52^{\circ} 47^{\prime \prime}$

1114

National Tank

Sec. 15,

ec. 32 ,

T. 30 N., R. 6 W.

$35^{\circ} 53^{-} 44^{\prime \prime}$,

$35^{\circ} 56^{\circ} 45^{\prime \prime}$,

$112^{\circ} 56^{\circ} 34^{\prime \prime}$

$35^{\circ} 56^{-} 47^{\prime \prime}$

T. 30 N., R. 6 W.

$35^{\circ} 56^{\circ} 55^{\prime \prime}$,

National Tank Sec. 28 ,

T. 30 N., R. 6 W.

$112^{\circ} 56^{\circ} 13^{\prime \prime}$

$35^{\circ} 59^{\circ} 00^{\prime \prime}$,
$112^{\circ} 56^{\circ} 46^{\prime \prime}$
C?

C2

C2

c?

C?

C4

C4

C4

C4

C?
Depression with reddish soil; two-thirds surrounded by a ridge (fig. 20).

slight bowl in center filled with soil surrounded by a very low hill on three sides. Some gravels present; covered with basalt float (fig. 21).

Central hill surrounded by a concentric dralnage and outer riti of Harrisburg Gypsiferous Member dipping Inward $12^{\circ}-15^{\circ}$ (fig. 22).

Adjacent to 1107. A slight depression which is identical in size and shape to 1107. Inward-dipping beds of Harrisburg Gypsiferous Member (f1g. 22).

Large semicircular ridge with some trees bounding a broad, low grassy plain. Adjacent to 1108 .

Well-developed circular drainage around a central small hill covered with Kaibab float.

Arcuate row of trees surrounding a grassy plain on 3 sides.

A green grassy slight depression whtch contrasts sharply with the surrounding browner grassland (fig. 23).

Falrly well-developed closed depression. Small goethite concretions present (fig. 24).

Small depression of grass anid sagebrush surrounded by scattered funipers (fig. 25).

Reddish soll-covered depression with grass and sagebrush surrounded by scattered junipers (fig. 26).

Irregular shaped depression with grass and sagebrush surrounded by scattered junipers.

\section{${ }^{1}$ Collapses are categorized as follows:}

$\mathrm{C} 2$ = Concentric, Inward-d1pplng beds; no visible alteration

C4 = Distinctly circular feature, either due to vegetation or topography; no visible alteration or dipplng beds

C? = Questionable. A circular feature appears to be present, but with no obvious dipping beds, alteration, vegetation change, or topography delineation. 


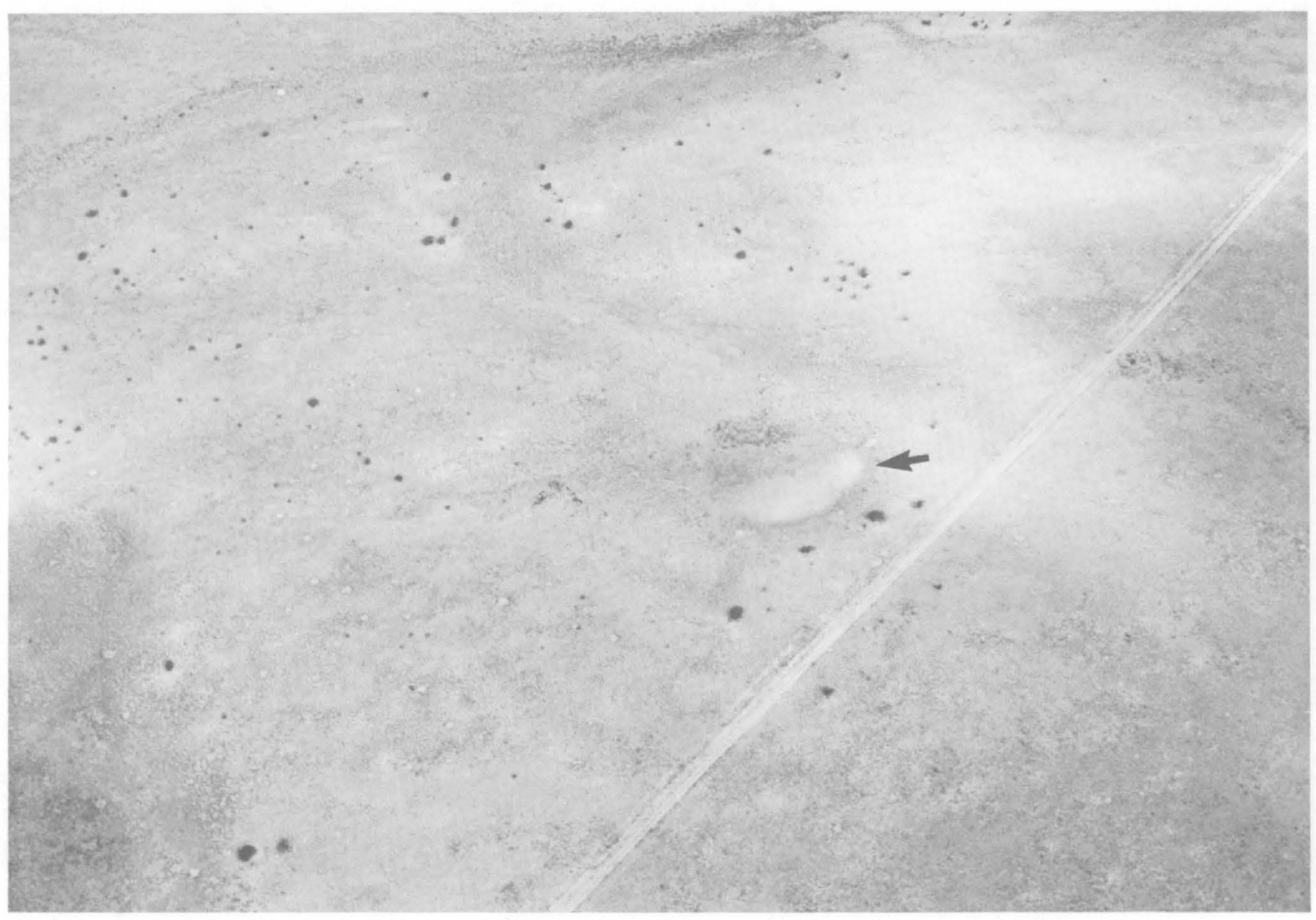

Figure 5. Collapse feature 525 (indicated by arrow) has been classified as a C4 because of its concentric drainage and vegetation growth. Photographed from a helicopter; view to the northwest.

The 25 collapse features listed in table 1 merit further study. Each feature is numbered on table 1 and is identified by that number on figure 4 . The collapses are grouped into three categories-C2, C4 and C?-based on their surface expression. Those features that show (1) concentric, inward-dipping beds are classified as "collapse 2" (C2); (2) a centripetal and concentric drainage or a concentric vegetation pattern, but no outcrop, are classified as "collapse 4" (C4); and (3) those which appear to be, at best, only a somewhat circular color change, or are otherwise questionable are classified as "collapse ?" (C?). None of the 25 collapse features showed any evidence of anomalous surface gamma radioactivity or supergene copper mineralization.

Collapse 562, similar in surface expression to collapses 569 and 570 , was drilled intermittently between 1984 and 1986 by Rocky Mountain Energy. This collapse is about one mile southeast of the reservation boundary, just south of the sharp bend along the eastern boundary.
Another similar collapse, 564 (fig. 3), was drilled in 1986 by Energy Fuels Nuclear. All four collapses have a white circular rim around a central depression that contains reddish soil. This slightly raised rim may be due to silicification from fluids moving along the ring fracture of the breccia pipe, and, hence, may be a favorable exploration criterion for locating breccia pipes.

\section{Description of Specific Collapse Features in the National Tank Area}

525-C4.-This feature is readily discernible as a circular structure but appears to be merely a sink hole (fig. 5). The mapped area is a circular depression that is intermittently filled with water and rimmed by vegetation darker than the surrounding terrain. Nevertheless, because of the dissolution of the Harrisburg Gypsiferous Member of the Kaibab Limestone and the Woods Ranch 


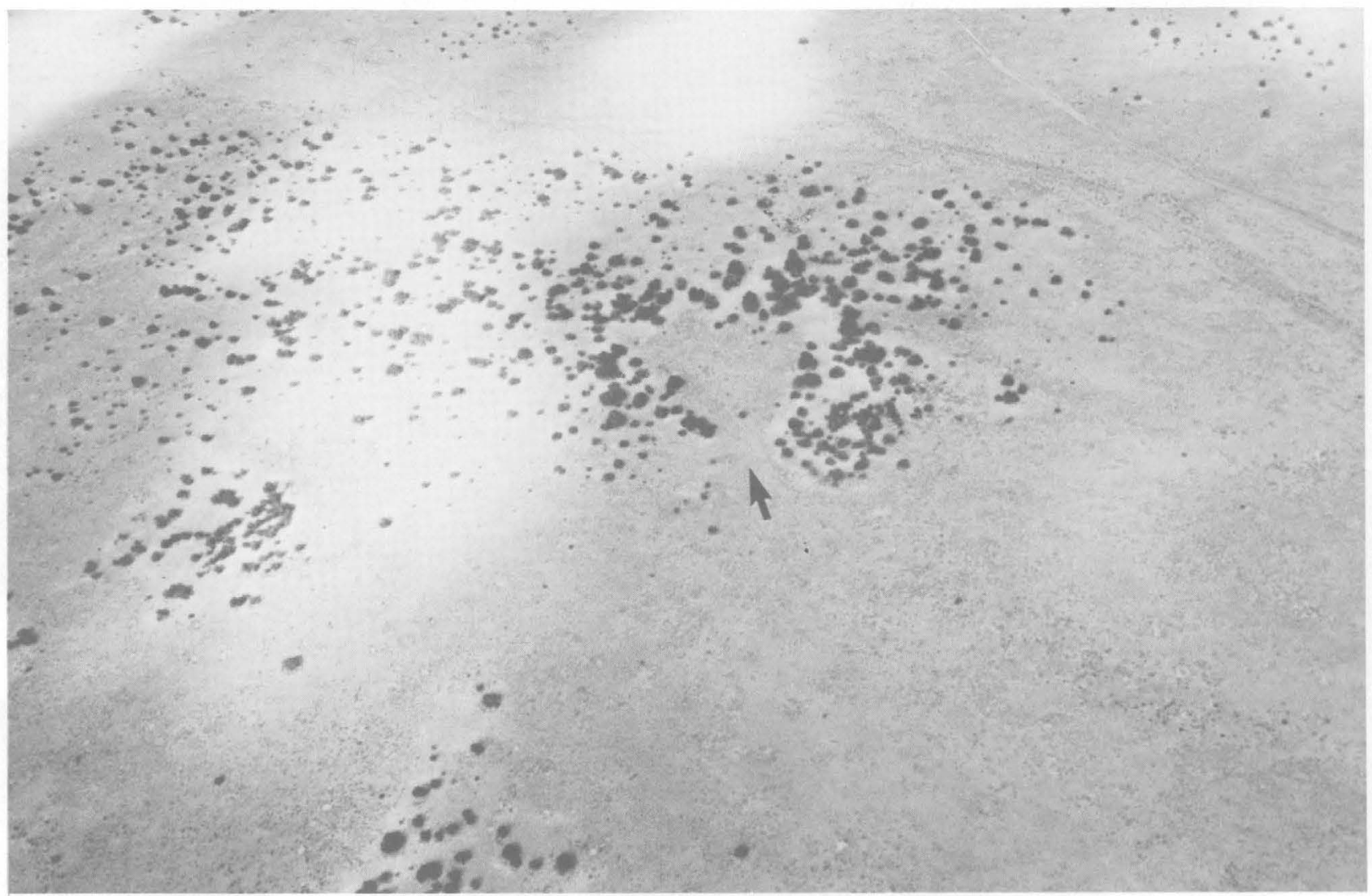

Figure 6. Collapse feature 531 (indicated by arrow), photographed from a helicopter, is expressed as a depression bordered on three sides by a low rim of Kaibab Limestone crowned with junipers. View to the west.

Member of the Toroweap Formation above known breccia pipes on the Coconino Plateau, unequivocal distinction between sink holes and breccia pipes from surface evidence becomes impossible. This feature does not have the vertical walls of a classical sink hole, but then there is no outcrop and the unconsolidated soil cover could have accumulated in the hole. Soil samples were collected from this feature in May 1986, but the data have not yet been compiled and plotted.

531-C4.-This feature was mapped as a solution collapse because of its raised arcuate rim around a nearly closed basin (fig. 6). The basin contains sagebrush and the rim supports a denser growth of junipers than does the surrounding landscape. The rim of Kaibab Limestone resembles the rim around collapse features 562, 564, 569 , and 570. Feature 562 is a mineralized breccia pipe, and hence the other three features have good potential too. Nevertheless, the depression and rim in feature 531 are not as pronounced or complete as they are in collapse features $562,564,569$, or 570 . This area has no outcrop. Soil samples were collected from this feature in May
1986, but the data have not yet been compiled and plotted. Audio-magnetotelluric soundings do not show any significant conductive zone beneath the center of the collapse, although two minor zones occur beneath the rim.

534-C4.-This locality is a more obvious circular feature than features 525 or 531 , although the relief of the rim does not look pronounced in either the helicopter photograph (fig. 7A) or the aerial photographic view (fig. 7B). The feature is a relatively large almost-closed depression, although there is no enhanced vegetation growth. Some rock outcrops along the rim and dips inward on the north side.

Because many such collapse features on the high plateaus are covered by soil and low ground vegetation, with little outcrop, soil geochemistry appears to be an inexpensive means of acquiring additional information on the possible presence of subsurface mineralization. Good analytical accuracy, precision, and low detection limits are necessary because soil anomalies over the breccia pipes are very low level. Soil surveys were made 

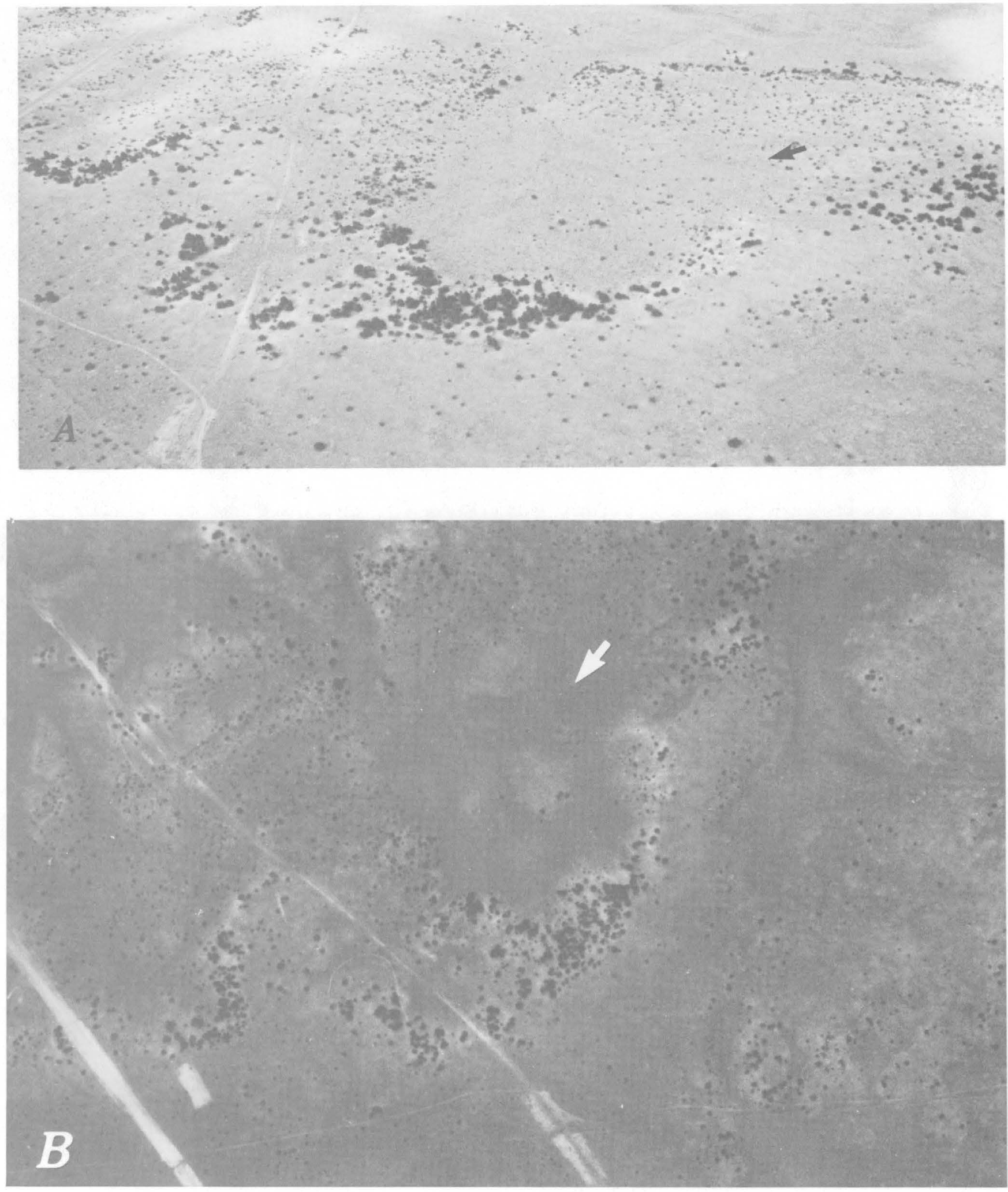

Figure 7. Collapse feature 534 (indicated by arrow) is an obvious circular feature, although there are no distinct concentric vegetation or soil patterns. Outcrop of Kaibab Limestone on north side dips inward. A, Photograph from a helicopter (view to the southwest). B, low-altitude aerial photograph shows the feature belongs in the $\mathrm{C} 4$ category. Up on the photo is to the west. 


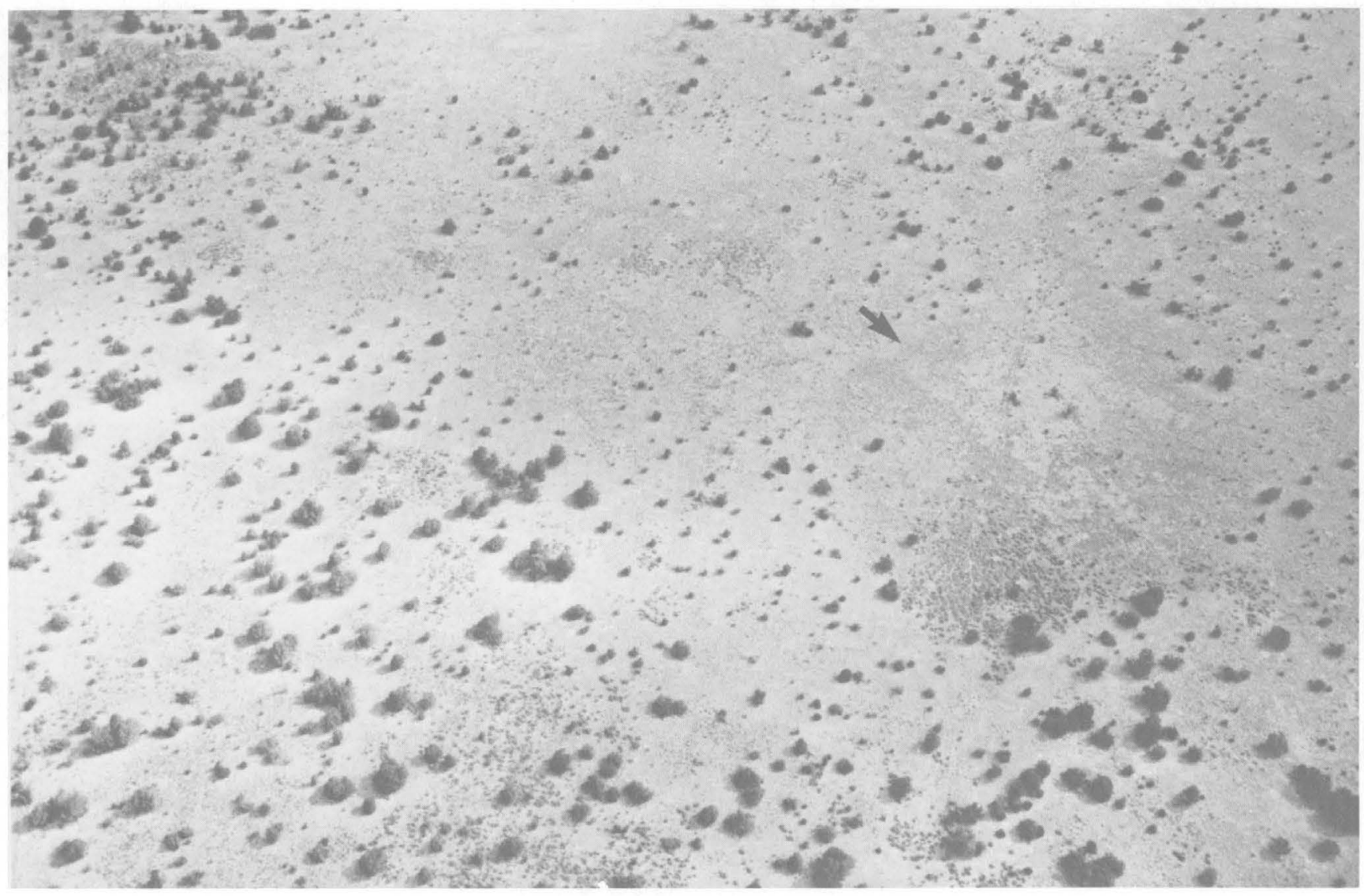

Figure 8. Collapse feature 537 (indicated by arrow). Photograph was taken from a helicopter. The feature is in the right center of the picture and stands out because of the darker green circular vegetation patch.

of collapse feature 534 in 1984 and 1986. Preliminary results from the 1984 study show some significant element anomalies in the soil over the structure. Of the 33 elements determined for 23 samples, $\mathrm{Co}, \mathrm{Cu}, \mathrm{Fe}, \mathrm{Mn}$, $\mathrm{Ni}, \mathrm{Pb}$, and $\mathrm{Zn}$ appear to increase in the soil over the collapse compared with soil of the surrounding terrain and $\mathrm{Mg}$ appears to decrease. With the exception of $\mathrm{Mn}$, all the elements enriched in the soil over the collapse are ones that are commonly enriched in, or form, the breccia pipe orebodies.

Helium surveys over breccia pipes have shown mixed success. Positive helium anomalies were observed over one known mineralized pipe but not over another. Collapse feature 534 is one of the few collapse features surveyed that showed a helium anomaly, although it was only twice background.

Slingram and very low frequency (VLF) data, a time-domain electromagnetic (TDEM) profile, and an electric section are presented in Senterfit and others (1985). The TDEM data show a distinct change in resistivity at a depth of about $960 \mathrm{ft}(290 \mathrm{~m})$; this is approximately the same depth as the top of the Seligman (sandstone) Member of the Toroweap Formation in the center of the Mohawk Canyon breccia pipe (Wenrich and others, 1988). At the margin of the Mohawk Canyon pipe, the Seligman Member was encountered more than $100 \mathrm{ft}$ (at a depth of approximately $825 \mathrm{ft}$ ) higher than in the center of the pipe. So, because the rocks within the Mohawk Canyon pipe have been downdropped more than $100 \mathrm{ft}$, the top of the Seligman Member within the center of the pipe is at about $925 \mathrm{ft}$. If the units are approximately the same thickness in the National Tank area as at the Mohawk Canyon pipe about 15 miles away, the top of the Seligman Member in the middle of this structure is perhaps $130 \mathrm{ft}$ lower than in the adjacent section. Hence, structure 534 is likely a breccia pipe.

The results from soil geochemistry, helium soil gas, and TDEM geophysical surveys for collapse feature 534 all appear encouraging. Further studies may prove this to be a mineralized breccia pipe. 


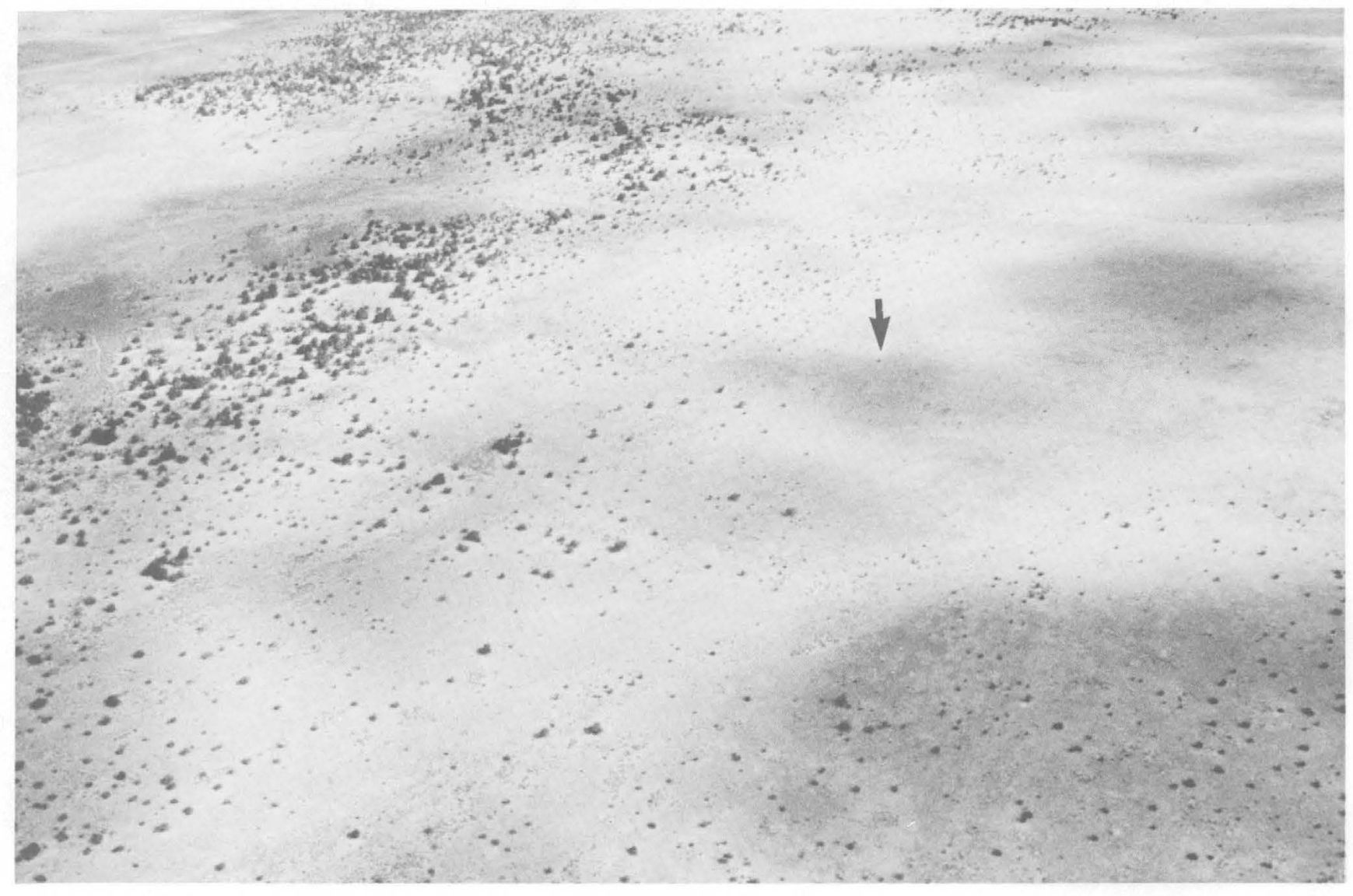

Figure 9. Collapse feature 538 (indicated by arrow). Photograph was taken from a helicopter. The feature is located in the center of the picture as a 2 -in. by 1.5-in. circular darker patch that appears from this oblique view as two smaller dark patches. Dark patches on the right side of the photograph are cloud shadows.

537-C?.-This feature (fig. 8) is similar to 525 in that it is a circular depression. The depression apparently accumulates water more than the surrounding terrain, as the vegetation within it is greener and forms a green circle. The soil appears to be a slightly redder than the soil in the surrounding terrain. This collapse feature has about the same low probability as 525 of being a breccia pipe.

538-C?.-On the aerial photograph this area appears as an anomalous, round, reddish soil patch. Yet, from the helicopter (fig. 9) it is difficult to recognize anything that resembles a distinctly circular feature; on the ground there is little to distinguish the feature from the surrounding terrain. The area in question is shown in the center of figure 9 where it is about 2 in. by 1.5 in.; the oblique angle from which the photograph was taken distorts the circularity of the patch. This feature is probably the most questionable of the 25 collapse features listed in table 1.
539-C?.-This feature is almost as questionable as 538. It is a circular patch of sagebrush (fig. 10) that appears somewhat greener than the surrounding terrain during the summer months, as if water were accumulating in a slight depression.

569-C4.-Based on surface morphology, this collapse structure is one of the more favorable features in the National Tank area, in that it has a closed depression surrounded by a low rim of Harrisburg Gypsiferous Member of the Kaibab Limestone. This feature also resembles, except for its more elliptically shaped depression, collapse feature 562 drilled by Rocky Mountain Energy. As is commonly the case, the collapse structure is not as obvious in a photograph from a helicopter (fig. 11A), as it is in a low-altitude aerial photograph (fig. 11B). Unfortunately, there is little outcrop, and the few exposed beds appear to be flat lying, in contrast to the more favorable characteristic of inward-tilted beds. 


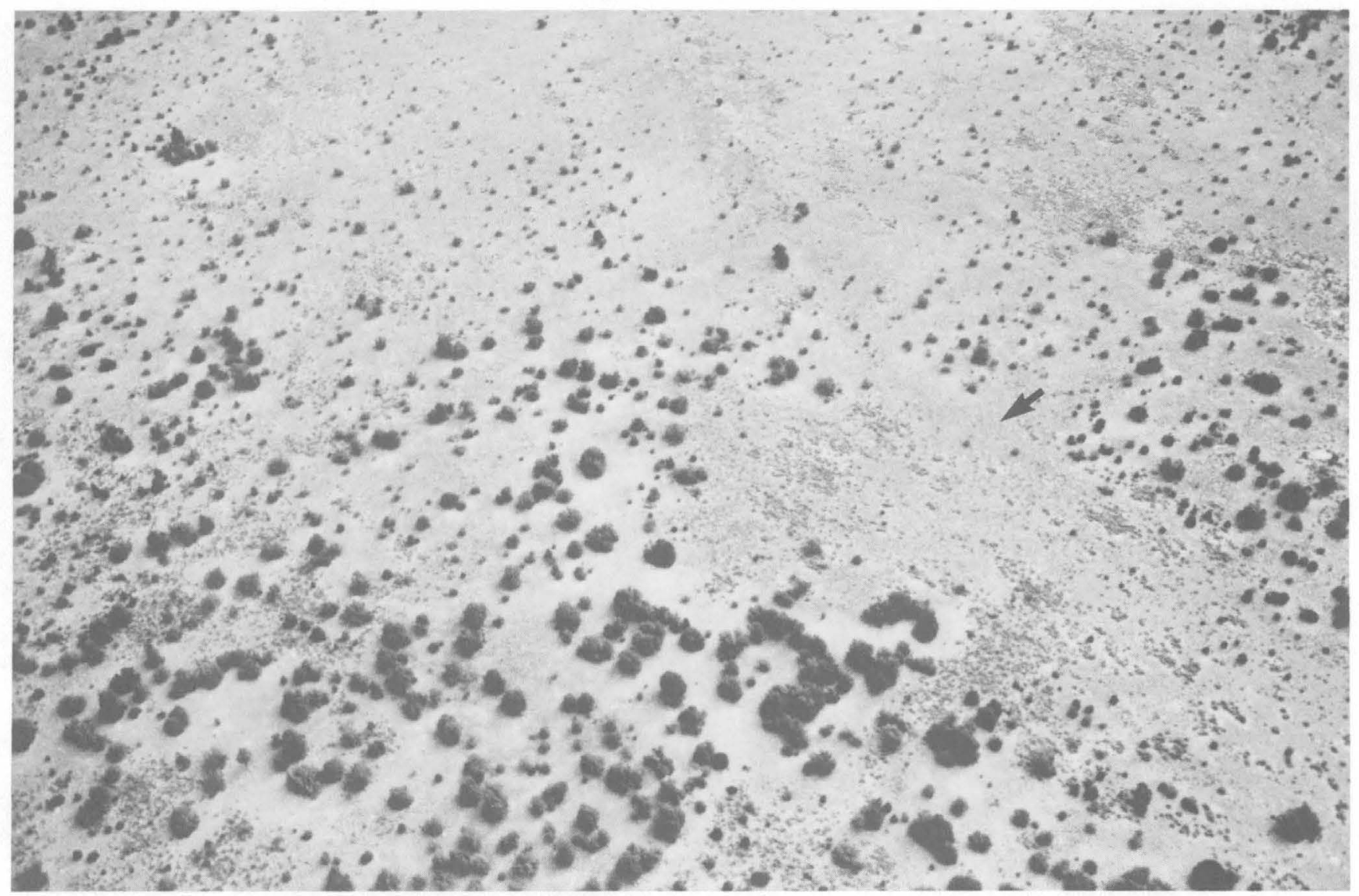

Figure 10. Collapse feature 539 (indicated by arrow), photographed from a helicopter, has a slightly greener circular patch of sage just to the right of center.

A preliminary soil survey completed over this structure in July 1984, was not very informative because only seven samples were collected. The sparse data suggest that $\mathrm{Mn}, \mathrm{Ni}$ and $\mathrm{Sr}$ may be enriched in the soil over the collapse, as compared with the surrounding terrain, and $\mathrm{Ca}, \mathrm{Mg}$, and $\mathrm{Pb}$ may be depleted.

A helium soil-gas survey was completed over this structure in March 1985 (Reimer, 1985). The mean helium concentration measured inside the depression was identical to that of the background area, $1,500 \mathrm{ft}$ to the southwest. A similar survey (also in March, 1985), run over a structure known to be a mineralized breccia pipe (feature 562) showed that helium concentrations were approximately $50 \mathrm{ppb}$ higher in the pipe than around it (Reimer, 1985); in addition, in the central part of the mineralized pipe the helium values were more than $200 \mathrm{ppb}$ higher than background. In June 1985, a second helium survey was made over collapse feature 569 (G.M. Reimer, written commun., 1986); a couple of samples, from the east side of the peanut-shaped depression, were anomalous, but an inadequate number of background samples were collected to accurately define "anomalous."

Audio-magnetotelluric soundings over collapse 569 detected a conductive zone lying southeast of the center of the depression (Flanigan and others, 1986). Although Flanigan and others (1986) believed this conductive zone to be small, and thus they suggest the feature is "a questionable breccia pipe," it is interesting to note that this zone is the same area where Reimer detected the highest helium soil-gas measurements. A ground magnetometer survey conducted over collapse 569 detected two areas of anomalous high magnetic values and two areas of anomalous low magnetic values (probably two separate dipole anomalies), suggesting that the feature's peanut shape may represent the surface manifestation of two intergrown breccia pipes (Van Gosen and Wenrich, 1989).

570-C4-This collapse structure is nearly identical in morphology to the drilled feature 562, except that it is 

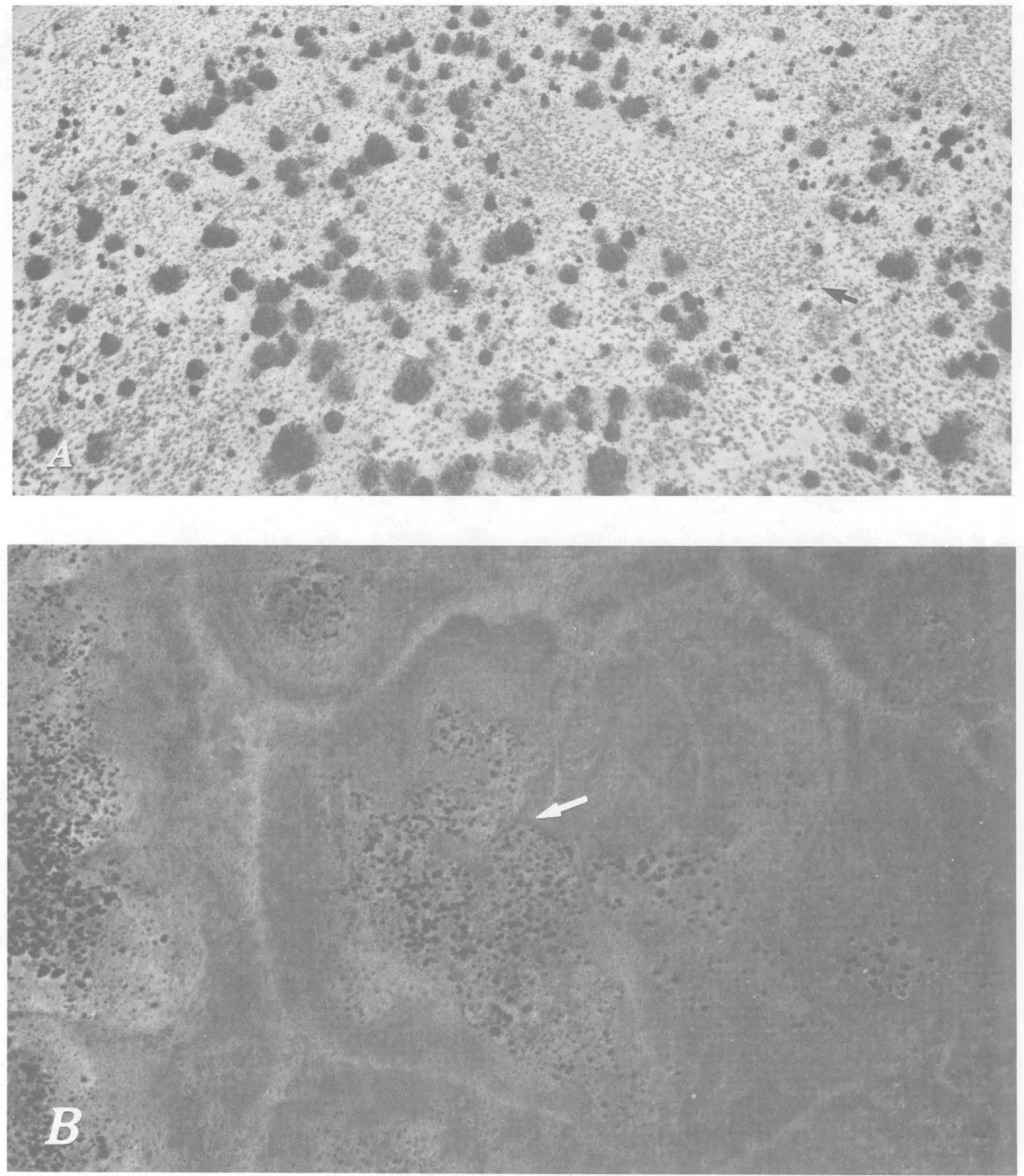

Figure 11. Collapse feature 569 (indicated by arrow) is a semi-closed depression, surrounded by a low rim mantled by junipers and pinyon pines. The view in both photographs is to the north. A, Photograph taken from a helicopter; B, 1:24,000 aerial photograph (but reproduced at a different scale) shows feature 569 as a distinct circular white rim of rocks mantled by scattered trees, surrounding a peanut-shaped closed depression. $150 \mathrm{ft}$ by $300 \mathrm{ft}$. 


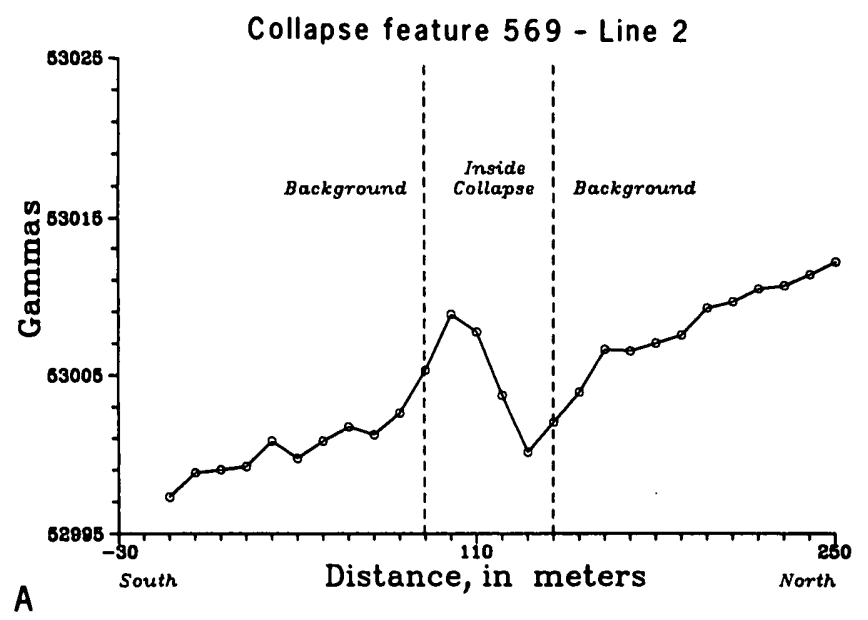

A

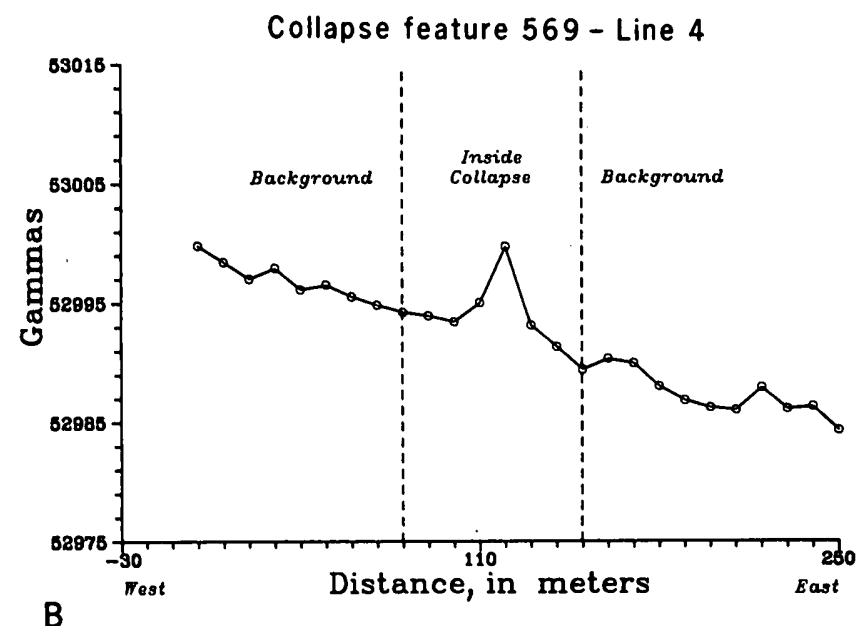

Figure 12. Ground magnetometer traverse over collapse feature 569. A, North-south. Note the strong positive and negative (dipole) anomaly. B, East-west. Note the positive anomaly over the center of the pipe.

not a closed depression. Rather it is breached on one side. The depression is bordered on three sides by a rim of Kaibab Limestone. Both near-surface (fig. 13A) and low-altitude (fig. 13B) aerial views show a distinctly circular feature with a raised rim of what appears to be whiter Kaibab Limestone.

Soil sampling traverses across collapse 570 show significant positive enrichments that are 1.5-10 times background for $\mathrm{Cu}, \mathrm{Pb}$, and $\mathrm{Zn}$ concentrations in soil over the center of the collapse. Concentrations of $\mathrm{Ag}$ and $\mathrm{Tl}$ are also anomalous but to a lesser degree.

Over collapse 570, AMT soundings reveal a pipeshaped, strongly conductive zone with a diameter of about $300 \mathrm{ft}$, extending to a depth of at least $1,900 \mathrm{ft}$ (Flanigan and others, 1986). The most conductive part of the breccia pipe throat appears to plunge to the southwest. The shape of the highly conductive zone of this collapse is similar to that of the EZ-2 ore-containing breccia pipe (also shown in Flanigan and others, 1986). This apparent tilt to the presumed breccia pipe should be incorporated into the design of any future drilling project; that is, if a breccia pipe orebody is present, it is probably located under the southwest part of the depression. Ground magnetometer surveys over this collapse feature reveal a relatively featureless, consistent local magnetic gradient, thus providing weaker evidence than the AMT soundings for an underlying breccia pipe (Van Gosen and Wenrich, 1989).

A helium soil-gas survey over collapse 570 shows no significant anomalies within the feature (G.M. Reimer, written commun., 1986). Helium surveys don't appear to provide definitive results even over known orebodies, so the helium results for collapse 570 do not particularly deter from the favorable AMT and soil survey results. This collapse has perhaps the greatest potential for being a breccia pipe of the 25 described here. In addition to the favorable geochemical and geophysical surveys, the morphology is similar to that of breccia pipes 562 and 564 .

571-C4.-Collapse feature 571 is approximately half the size of 570 , but is also a circular depression surrounded by a white rim (fig. 14A,B). The soil inside this 10- to 13-ft-deep depression is somewhat darker than the surrounding terrain, and the vegetation growth denser.

A soil survey conducted over this collapse structure showed significant anomalies that suggest that this feature is at least a sink hole, if not a mineralized breccia pipe. Samples shown in figures $15 A-H$ were all collected approximately 4 in. $(10 \mathrm{~cm})$ below the surface. The samples were dry-sieved through 80 mesh $(177 \mathrm{~m})$ stainless steel sieves to remove the large rock chips and coarse organic debris. Four traverses were made across the feature, and four background samples were collected, each about $100 \mathrm{ft}$ beyond the margin of the pipe. The background samples are consistently lower in metal content than the samples taken within the feature; metal content of samples taken in the ring fracture $(100-150 \mathrm{ft}$ from center) is as low as the background samples, with the exception of $\mathrm{Cu}$ and $\mathrm{Mg}$. Supergene copper minerals are commonly found in the ring fracture of mineralized pipes, so it would not be surprising to find a $\mathrm{Cu}$ anomaly in the soil overlying the ring fracture in a mineralized pipe. The raw data are shown in table 2 . Of the 29 elements determined, all but 3 appear to be positively enriched over the center of the collapse as compared with background samples from outside the collapse. Of these, 15-Al, Ba, Co, Ce, Cr, Cu, Fe, Mg, Mn, Pb, Sc, Tl, V, Y, and $\mathrm{Zn}-$ are strongly enriched in soil within the 

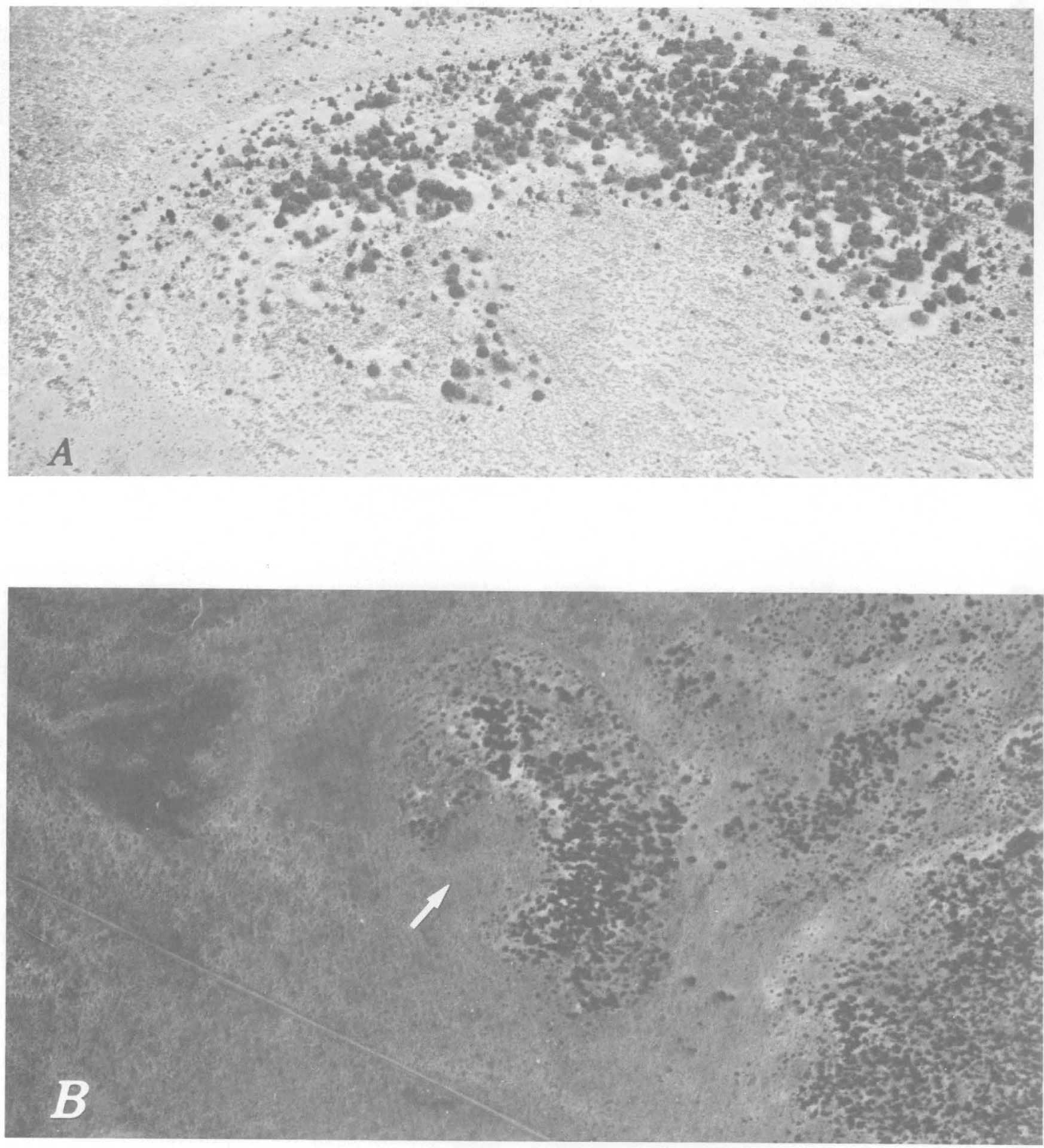

Figure 13. A, This photograph, taken several hundred feet above the ground surface from a helicopter, of collapse 570 shows a low rim of white rock (Harrisburg Gypsiferous Member of the Kaibab Limestone) bordering a depression on three sides. The depression is about $600 \mathrm{ft}$ in diameter. View is to the west. B, This low-altitude view of collapse feature 570 (indicated by arrow) looks very similar to the helicopter view, except that with the smaller scale it is apparent that this feature has a slightly greater concentration of trees on its slightly whiter rim of rock than the adjacent terrain. View is to the southwest. 

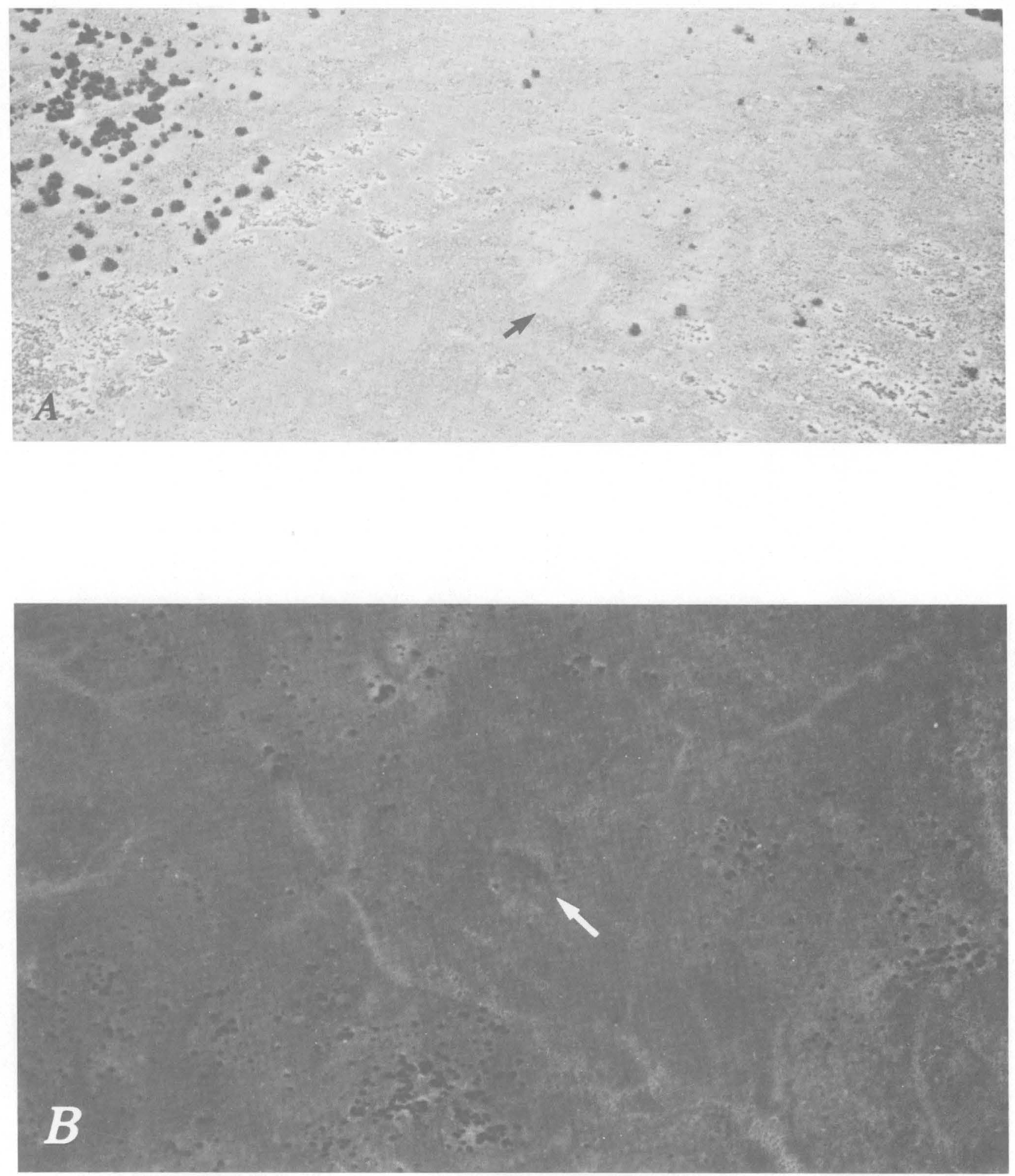

Figure 14. Collapse feature 571 (indicated by arrow). A, Photograph taken from a helicopter shows a 10- to 13-ft-deep depression surrounded by a white rim. View is to the northeast. B, In this low-altitude aerial photograph, 571 resembles a small sink hole, with darker vegetation than the surrounding terrain. View is to the northwest. 
Table 2. Chemical analyses of soil samples collected from collapse feature 571

[Latitude 35 $53^{\prime} 6^{\prime \prime}$ " longitude $112^{\circ} 54^{\prime} 06^{\prime \prime}$. Sample numbers with an " $\mathrm{R}$ " rather than a " $C$ " in the 5th digit are analytical replicate samples of the preceding sample that has the same first four digits. Leader $(-)$ indicates no data. All but two analyses are by inductively coupled argon emmission plasma spectroscopy; uranium and thorium are by delayed neutron. All analytical values are reported in parts per million unless otherwise noted]

\begin{tabular}{|c|c|c|c|c|c|c|c|c|c|c|c|}
\hline $\begin{array}{l}\text { Sample } \\
\text { number }\end{array}$ & Traverse & $\begin{array}{l}\text { Sample } \\
\text { depth } \\
\text { (1n.) }\end{array}$ & $\begin{array}{l}\text { Distance } \\
\text { from center } \\
\text { ( } f t)\end{array}$ & Al $x$ & As & Be & Be & $\mathrm{Ca} \mathrm{F}$ & $\mathrm{Ce}$ & Co & $\mathrm{Cr}$ \\
\hline $\begin{array}{ll}1 & 571 \text { ASC84 } \\
2 & 571 B S C 84 \\
3 & 571 C S C 84 \\
4 & 5710 S C 84 \\
5 & 571 \text { ESC84 }\end{array}$ & $\begin{array}{c}\text { Al1 } \\
\text { Al1 } \\
\text { NE-SW } \\
\text { NE-SW } \\
\text { NE-SW }\end{array}$ & $\begin{array}{l}4 \\
8 \\
4 \\
8 \\
4\end{array}$ & $\begin{array}{r}0 \\
0 \\
75 \\
75 \\
75\end{array}$ & $\begin{array}{l}6.6 \\
7.2 \\
4.9 \\
4.6 \\
5.5\end{array}$ & $\begin{array}{l}<10 \\
<10 \\
<10 \\
<10 \\
<10\end{array}$ & $\begin{array}{l}560 \\
580 \\
480 \\
450 \\
550\end{array}$ & $\begin{array}{l}2 \\
2 \\
1 \\
1 \\
1\end{array}$ & $\begin{array}{l}1.0 \\
1.1 \\
5.6 \\
8.5 \\
0.9\end{array}$ & $\begin{array}{l}75 \\
77 \\
54 \\
50 \\
61\end{array}$ & $\begin{array}{l}17 \\
14 \\
11 \\
10 \\
10\end{array}$ & $\begin{array}{l}65 \\
71 \\
53 \\
48 \\
52\end{array}$ \\
\hline $\begin{array}{rr}6 & 571 F S C 84 \\
7 & 571 \mathrm{GSC84} \\
8 & 571 \mathrm{HSC84} \\
9 & 571 \mathrm{ISC84} \\
10 & 571 \mathrm{JSC8}\end{array}$ & $\begin{array}{l}\mathrm{NE}-\mathrm{SW} \\
\mathrm{NW}-\mathrm{SE} \\
\mathrm{NW}-\mathrm{SE} \\
\mathrm{NW}-\mathrm{SB} \\
\mathrm{NW}-\mathrm{SE}\end{array}$ & $\begin{array}{l}8 \\
4 \\
8 \\
4 \\
4\end{array}$ & $\begin{array}{l}75 \\
75 \\
75 \\
75 \\
75\end{array}$ & $\begin{array}{l}5.9 \\
4.9 \\
5.3 \\
5.3 \\
5.1\end{array}$ & $\begin{array}{l}<10 \\
<10 \\
<10 \\
<10 \\
<10\end{array}$ & $\begin{array}{l}570 \\
500 \\
520 \\
500 \\
480\end{array}$ & $\begin{array}{l}2 \\
1 \\
1 \\
1 \\
1\end{array}$ & $\begin{array}{l}0.9 \\
0.6 \\
0.6 \\
3.0 \\
4.7\end{array}$ & $\begin{array}{l}63 \\
55 \\
56 \\
60 \\
61\end{array}$ & $\begin{array}{r}12 \\
8 \\
11 \\
9 \\
10\end{array}$ & $\begin{array}{l}62 \\
47 \\
53 \\
55 \\
52\end{array}$ \\
\hline $\begin{array}{ll}11 & 571 \mathrm{JSRC4} \\
12 & 571 \mathrm{KSC84} \\
13 & 571 \mathrm{LSC84} \\
14 & 5710 \mathrm{SC84} \\
15 & 571 \mathrm{PSC84}\end{array}$ & $\begin{array}{c}\mathrm{NW}-\mathrm{SB} \\
\mathrm{N}-\mathrm{S} \\
\mathrm{N}-\mathrm{S} \\
\mathrm{N}-\mathrm{S} \\
\mathrm{N}-\mathrm{S}\end{array}$ & $\begin{array}{l}8 \\
4 \\
4 \\
4 \\
4\end{array}$ & $\begin{array}{r}75 \\
50 \\
100 \\
50 \\
100\end{array}$ & $\begin{array}{l}5.1 \\
5.7 \\
4.7 \\
5.7 \\
5.2\end{array}$ & $\begin{array}{l}<10 \\
<10 \\
<10 \\
<10 \\
<10\end{array}$ & $\begin{array}{l}480 \\
590 \\
490 \\
590 \\
520\end{array}$ & $\begin{array}{l}1 \\
1 \\
1 \\
2 \\
1\end{array}$ & $\begin{array}{l}4.7 \\
1.1 \\
4.4 \\
0.9 \\
0.8\end{array}$ & $\begin{array}{l}61 \\
72 \\
53 \\
67 \\
61\end{array}$ & $\begin{array}{r}9 \\
13 \\
8 \\
12 \\
11\end{array}$ & $\begin{array}{l}52 \\
63 \\
45 \\
62 \\
57\end{array}$ \\
\hline $\begin{array}{ll}16 & 571 \text { RSC84 } \\
17 & 5715 S C 84 \\
18 & 571 \text { USC84 } \\
19 & 571 \text { VSC84 }\end{array}$ & $\begin{array}{l}E-W \\
E-W \\
E-W \\
E-W\end{array}$ & $\begin{array}{l}4 \\
4 \\
4 \\
4\end{array}$ & $\begin{array}{r}50 \\
100 \\
50 \\
100\end{array}$ & $\begin{array}{l}6.6 \\
4.6 \\
5.9 \\
5.1\end{array}$ & $\begin{array}{l}<10 \\
<10 \\
<10 \\
<10\end{array}$ & $\begin{array}{l}630 \\
500 \\
580 \\
480\end{array}$ & $\begin{array}{l}2 \\
1 \\
2 \\
1\end{array}$ & $\begin{array}{l}0.9 \\
1.1 \\
1.1 \\
5.1\end{array}$ & $\begin{array}{r}77 \\
58 \\
6 \\
62\end{array}$ & $\begin{array}{r}16 \\
9 \\
13 \\
9\end{array}$ & $\begin{array}{l}68 \\
52 \\
62 \\
49\end{array}$ \\
\hline \multicolumn{12}{|c|}{ BACKGROUND SAMPLES } \\
\hline $\begin{array}{ll}20 & 571 \mathrm{MSC84} \\
21 & 571 \mathrm{MSRC4} \\
22 & 571 \mathrm{NSC84} \\
23 & 571 \mathrm{QSC84} \\
24 & 571 \mathrm{TSC84} \\
25 & 571 \text { WSC84 } \\
\end{array}$ & $\begin{array}{l}N-S \\
N-S \\
N-S \\
N-S \\
E-W \\
E-W \\
\end{array}$ & $\begin{array}{l}4 \\
4 \\
8 \\
4 \\
4 \\
4\end{array}$ & $\begin{array}{l}300 \\
300 \\
300 \\
300 \\
300 \\
300 \\
\end{array}$ & $\begin{array}{l}4.9 \\
5 \\
5.1 \\
4.8 \\
4.8 \\
5.3 \\
\end{array}$ & $\begin{array}{r}<10 \\
<10 \\
<10 \\
20 \\
<10 \\
<10 \\
\end{array}$ & $\begin{array}{l}480 \\
500 \\
470 \\
500 \\
510 \\
550 \\
\end{array}$ & $\begin{array}{l}1 \\
1 \\
1 \\
1 \\
1 \\
2 \\
\end{array}$ & $\begin{array}{l}1.7 \\
1.8 \\
2.2 \\
0.6 \\
0.7 \\
0.8\end{array}$ & $\begin{array}{l}53 \\
62 \\
55 \\
59 \\
62 \\
71 \\
\end{array}$ & $\begin{array}{r}8 \\
8 \\
8 \\
8 \\
9 \\
11 \\
\end{array}$ & $\begin{array}{l}51 \\
50 \\
51 \\
51 \\
50 \\
58\end{array}$ \\
\hline
\end{tabular}

\begin{tabular}{|c|c|c|c|c|c|c|c|c|c|c|c|c|c|c|}
\hline & iample no. & $\mathrm{Cu}$ & Fe 2 & Ga & $\mathrm{Hg}$ & $\mathrm{K} \pi$ & La & LA & $\operatorname{Mg} Z$ & in & $\mathrm{NaZ}$ & Nb & Nd & $\mathrm{Ni}$ \\
\hline & $\begin{array}{l}571 \text { ASC84 } \\
571 \mathrm{BSC84} \\
571 \mathrm{CSC84} \\
571 \mathrm{DSC84} \\
571 \mathrm{ESC84}\end{array}$ & $\begin{array}{l}35 \\
37 \\
23 \\
23 \\
21\end{array}$ & $\begin{array}{l}3.3 \\
3.5 \\
2.2 \\
2.1 \\
2.5\end{array}$ & $\begin{array}{l}16 \\
18 \\
12 \\
11 \\
12\end{array}$ & $\begin{array}{c}- \\
0.03 \\
- \\
-\end{array}$ & $\begin{array}{l}1.9 \\
2.2 \\
2.1 \\
1.9 \\
2.3\end{array}$ & $\begin{array}{l}39 \\
40 \\
30 \\
28 \\
33\end{array}$ & $\begin{array}{l}34 \\
37 \\
28 \\
27 \\
28\end{array}$ & $\begin{array}{l}1.1 \\
1.1 \\
1.2 \\
1.2 \\
0.8\end{array}$ & $\begin{array}{r}1200 \\
1100 \\
480 \\
390 \\
710\end{array}$ & $\begin{array}{l}0.71 \\
0.67 \\
0.50 \\
0.46 \\
0.70\end{array}$ & $\begin{array}{r}11 \\
11 \\
6 \\
7 \\
9\end{array}$ & $\begin{array}{l}32 \\
36 \\
27 \\
28 \\
28\end{array}$ & $\begin{array}{l}33 \\
36 \\
38 \\
37 \\
24\end{array}$ \\
\hline & $\begin{array}{l}571 \mathrm{FSC84} \\
571 \mathrm{GSC84} \\
571 \mathrm{HSC84} \\
571 \mathrm{ISC84} \\
571 \mathrm{JSC84}\end{array}$ & $\begin{array}{l}26 \\
23 \\
33 \\
26 \\
27\end{array}$ & $\begin{array}{l}2.8 \\
2.3 \\
2.5 \\
2.4 \\
2.3\end{array}$ & $\begin{array}{l}11 \\
11 \\
12 \\
13 \\
12\end{array}$ & $\begin{array}{l}- \\
\overline{-} \\
-\end{array}$ & $\begin{array}{l}2.3 \\
2.0 \\
1.8 \\
2.0 \\
2.2\end{array}$ & $\begin{array}{l}36 \\
31 \\
33 \\
33 \\
32\end{array}$ & $\begin{array}{l}30 \\
30 \\
31 \\
28 \\
27\end{array}$ & $\begin{array}{l}0.9 \\
0.6 \\
0.7 \\
1.1 \\
1.1\end{array}$ & $\begin{array}{l}710 \\
460 \\
480 \\
560 \\
500\end{array}$ & $\begin{array}{l}0.69 \\
0.44 \\
0.49 \\
0.58 \\
0.54\end{array}$ & $\begin{array}{l}7 \\
8 \\
7 \\
8 \\
8\end{array}$ & $\begin{array}{l}28 \\
26 \\
30 \\
30 \\
30\end{array}$ & $\begin{array}{l}26 \\
23 \\
25 \\
25 \\
24\end{array}$ \\
\hline $\begin{array}{l}11 \\
12 \\
13 \\
14 \\
15\end{array}$ & $\begin{array}{l}571 \mathrm{JSRC4} \\
571 \mathrm{KSC84} \\
571 \mathrm{LSC84} \\
5710 \mathrm{SC84} \\
571 \mathrm{PSC84}\end{array}$ & $\begin{array}{l}28 \\
22 \\
20 \\
25 \\
22\end{array}$ & $\begin{array}{l}2.3 \\
2.6 \\
2.1 \\
2.7 \\
2.4\end{array}$ & $\begin{array}{l}12 \\
15 \\
12 \\
12 \\
13\end{array}$ & $\begin{array}{l}- \\
\overline{-} \\
- \\
-\end{array}$ & $\begin{array}{l}2.0 \\
2.2 \\
1.7 \\
2.4 \\
2.2\end{array}$ & $\begin{array}{l}31 \\
39 \\
28 \\
37 \\
34\end{array}$ & $\begin{array}{l}27 \\
28 \\
24 \\
28 \\
27\end{array}$ & $\begin{array}{l}1.1 \\
0.9 \\
0.8 \\
0.8 \\
0.8\end{array}$ & $\begin{array}{l}510 \\
790 \\
380 \\
810 \\
530\end{array}$ & $\begin{array}{l}0.55 \\
0.72 \\
0.59 \\
0.73 \\
0.55\end{array}$ & $\begin{array}{r}6 \\
<4 \\
7 \\
8 \\
<4\end{array}$ & $\begin{array}{l}29 \\
30 \\
28 \\
29 \\
28\end{array}$ & $\begin{array}{l}25 \\
39 \\
22 \\
25 \\
36\end{array}$ \\
\hline $\begin{array}{l}16 \\
17 \\
18 \\
19\end{array}$ & $\begin{array}{l}571 \text { RSC84 } \\
571 \text { SSC84 } \\
571 \text { USC84 } \\
571 \text { VSC84 }\end{array}$ & $\begin{array}{l}34 \\
19 \\
26 \\
23\end{array}$ & $\begin{array}{l}3.3 \\
2.2 \\
2.7 \\
2.3\end{array}$ & $\begin{array}{l}15 \\
11 \\
15 \\
12\end{array}$ & $\begin{array}{l}- \\
- \\
-\end{array}$ & $\begin{array}{l}2.1 \\
1.7 \\
2.3 \\
1.8\end{array}$ & $\begin{array}{l}42 \\
31 \\
36 \\
32\end{array}$ & $\begin{array}{l}35 \\
25 \\
30 \\
26\end{array}$ & $\begin{array}{l}0.9 \\
0.8 \\
1.0 \\
1.0\end{array}$ & $\begin{array}{r}1200 \\
460 \\
790 \\
470\end{array}$ & $\begin{array}{l}0.75 \\
0.51 \\
0.71 \\
0.60\end{array}$ & $\begin{array}{r}10 \\
7 \\
11 \\
8\end{array}$ & $\begin{array}{l}36 \\
28 \\
32 \\
28\end{array}$ & $\begin{array}{l}32 \\
23 \\
42 \\
25\end{array}$ \\
\hline \multicolumn{15}{|c|}{ BACKGROUND SAMPLES } \\
\hline $\begin{array}{l}20 \\
21 \\
22 \\
23 \\
24 \\
25\end{array}$ & $\begin{array}{l}571 M S C 84 \\
571 M S R C 4 \\
571 N S C 84 \\
571 Q S C 84 \\
571 \mathrm{TSC8} 4 \\
571 \text { WSC84 }\end{array}$ & $\begin{array}{l}17 \\
19 \\
17 \\
18 \\
15 \\
16\end{array}$ & $\begin{array}{l}2.3 \\
2.4 \\
2.4 \\
2.3 \\
2.2 \\
2.5\end{array}$ & $\begin{array}{l}12 \\
13 \\
13 \\
11 \\
12 \\
13\end{array}$ & $\begin{array}{l}- \\
\overline{0} \\
- \\
- \\
-\end{array}$ & $\begin{array}{l}1.8 \\
1.7 \\
1.4 \\
2.0 \\
1.9 \\
1.8\end{array}$ & $\begin{array}{l}31 \\
35 \\
33 \\
32 \\
37 \\
39\end{array}$ & $\begin{array}{l}34 \\
34 \\
35 \\
31 \\
30 \\
31\end{array}$ & $\begin{array}{l}0.6 \\
0.6 \\
0.6 \\
0.5 \\
0.6 \\
0.7\end{array}$ & $\begin{array}{l}360 \\
370 \\
360 \\
420 \\
370 \\
560 \\
\end{array}$ & $\begin{array}{l}0.41 \\
0.45 \\
0.38 \\
0.48 \\
0.40 \\
0.58\end{array}$ & $\begin{array}{l}8 \\
7 \\
8 \\
9 \\
6 \\
6 \\
\end{array}$ & $\begin{array}{l}28 \\
33 \\
31 \\
27 \\
31 \\
32 \\
\end{array}$ & $\begin{array}{l}24 \\
25 \\
25 \\
23 \\
35 \\
23\end{array}$ \\
\hline
\end{tabular}


Table 2. Chemical analyses of soil samples collected from collapse feature 571-Continued

\begin{tabular}{|c|c|c|c|c|c|c|c|c|c|c|c|c|c|}
\hline Sample no. & $P x$ & $\mathbf{P b}$ & Sc & $\mathrm{Se}$ & Sr & Th & $\begin{array}{l}\text { Th } \\
(\mathrm{DN})^{1}\end{array}$ & Ti $x$ & $\begin{array}{c}\mathbf{U} \\
(\mathrm{DN})^{\mathbf{l}}\end{array}$ & $\mathbf{v}$ & $\mathbf{Y}$ & $\mathrm{Yb}$ & Zn \\
\hline $\begin{array}{ll}1 & 571 \mathrm{ASC} \\
2 & 571 \mathrm{BSC} 4 \\
3 & 571 \mathrm{CSC} 84 \\
4 & 571 \mathrm{DSC84} \\
5 & 571 \mathrm{ESC} 84\end{array}$ & $\begin{array}{l}0.09 \\
0.09 \\
0.10 \\
0.09 \\
0.08\end{array}$ & $\begin{array}{l}19 \\
16 \\
14 \\
12 \\
16\end{array}$ & $\begin{array}{r}10 \\
11 \\
7 \\
7 \\
8\end{array}$ & $\begin{array}{c}- \\
<0.1 \\
- \\
-\end{array}$ & $\begin{array}{l}140 \\
130 \\
130 \\
130 \\
130\end{array}$ & $\begin{array}{r}12 \\
12 \\
8 \\
7 \\
10\end{array}$ & $\begin{array}{c}12.4 \\
- \\
8.9 \\
10.0 \\
11.3\end{array}$ & $\begin{array}{l}0.37 \\
0.38 \\
0.27 \\
0.24 \\
0.30\end{array}$ & $\begin{array}{l}2.9 \\
- \\
2.6 \\
2.3 \\
2.8\end{array}$ & $\begin{array}{l}64 \\
67 \\
48 \\
45 \\
50\end{array}$ & $\begin{array}{l}24 \\
25 \\
16 \\
15 \\
19\end{array}$ & $\begin{array}{l}2 \\
2 \\
2 \\
2 \\
2\end{array}$ & $\begin{array}{r}120 \\
120 \\
62 \\
55 \\
75\end{array}$ \\
\hline $\begin{array}{rl}6 & 571 \mathrm{FSC84} \\
7 & 571 \mathrm{GSC} 84 \\
8 & 571 \mathrm{HSC84} \\
9 & 571 \mathrm{ISC8} 4 \\
10 & 571 \mathrm{JSC} 84\end{array}$ & $\begin{array}{l}0.08 \\
0.04 \\
0.04 \\
0.09 \\
0.10\end{array}$ & $\begin{array}{l}19 \\
16 \\
25 \\
13 \\
14\end{array}$ & $\begin{array}{l}9 \\
7 \\
7 \\
8 \\
7\end{array}$ & $\begin{array}{l}- \\
- \\
- \\
-\end{array}$ & $\begin{array}{l}130 \\
100 \\
110 \\
120 \\
120\end{array}$ & $\begin{array}{r}9 \\
10 \\
12 \\
10 \\
9\end{array}$ & $\begin{array}{r}9.3 \\
11.0 \\
11.1 \\
10.2 \\
9.6\end{array}$ & $\begin{array}{l}0.32 \\
0.26 \\
0.28 \\
0.29 \\
0.27\end{array}$ & $\begin{array}{l}3.1 \\
2.2 \\
2.6 \\
3.1 \\
2.6\end{array}$ & $\begin{array}{l}54 \\
50 \\
53 \\
51 \\
48\end{array}$ & $\begin{array}{l}20 \\
17 \\
19 \\
19 \\
18\end{array}$ & $\begin{array}{l}2 \\
2 \\
2 \\
2 \\
2\end{array}$ & $\begin{array}{l}77 \\
55 \\
62 \\
66 \\
62\end{array}$ \\
\hline $\begin{array}{ll}11 & 571 \text { JSRC4 } \\
12 & 571 \mathrm{KSC8} 4 \\
13 & 571 \mathrm{LSC8} 4 \\
14 & 5710 \mathrm{SC8} 4 \\
15 & 571 \mathrm{PSC} 84\end{array}$ & $\begin{array}{l}0.09 \\
0.09 \\
0.08 \\
0.07 \\
0.06\end{array}$ & $\begin{array}{l}12 \\
17 \\
13 \\
18 \\
15\end{array}$ & $\begin{array}{l}7 \\
9 \\
7 \\
8 \\
8\end{array}$ & $\begin{array}{l}- \\
- \\
- \\
-\end{array}$ & $\begin{array}{l}120 \\
140 \\
130 \\
140 \\
120\end{array}$ & $\begin{array}{r}9 \\
9 \\
9 \\
12 \\
9\end{array}$ & $\begin{array}{l}9.6 \\
10.7 \\
11.7 \\
11.2 \\
10.8\end{array}$ & $\begin{array}{l}0.27 \\
0.33 \\
0.27 \\
0.32 \\
0.28\end{array}$ & $\begin{array}{l}2.9 \\
3.0 \\
2.6 \\
3.0 \\
2.9\end{array}$ & $\begin{array}{l}49 \\
52 \\
44 \\
55 \\
51\end{array}$ & $\begin{array}{l}18 \\
22 \\
15 \\
20 \\
19\end{array}$ & $\begin{array}{l}2 \\
2 \\
2 \\
2 \\
2\end{array}$ & $\begin{array}{l}62 \\
88 \\
56 \\
73 \\
65\end{array}$ \\
\hline $\begin{array}{ll}16 & 571 \mathrm{RSC} 84 \\
17 & 571 \mathrm{SSC} 84 \\
18 & 571 \mathrm{USC} 84 \\
19 & 571 \mathrm{VSC} 4\end{array}$ & $\begin{array}{l}0.07 \\
0.11 \\
0.11 \\
0.08\end{array}$ & $\begin{array}{l}21 \\
13 \\
18 \\
14\end{array}$ & $\begin{array}{r}11 \\
6 \\
9 \\
7\end{array}$ & $\begin{array}{l}- \\
- \\
-\end{array}$ & $\begin{array}{l}150 \\
110 \\
140 \\
140\end{array}$ & $\begin{array}{r}12 \\
11 \\
10 \\
9\end{array}$ & $\begin{array}{l}13.1 \\
10.6 \\
11.7 \\
10.1\end{array}$ & $\begin{array}{l}0.39 \\
0.27 \\
0.32 \\
0.28\end{array}$ & $\begin{array}{l}3.0 \\
2.6 \\
2.8 \\
2.5\end{array}$ & $\begin{array}{l}66 \\
44 \\
56 \\
49\end{array}$ & $\begin{array}{l}25 \\
18 \\
20 \\
16\end{array}$ & $\begin{array}{l}3 \\
2 \\
2 \\
2\end{array}$ & $\begin{array}{r}110 \\
58 \\
79 \\
64\end{array}$ \\
\hline \multicolumn{14}{|c|}{ BACKGROUND SAMPLES } \\
\hline $\begin{array}{ll}20 & 571 M S C 84 \\
21 & 571 M S R C 4 \\
22 & 571 N S C 84 \\
23 & 571 \mathrm{QSC} 84 \\
24 & 571 \mathrm{TSC8} \\
25 & 571 \mathrm{WSC8}\end{array}$ & $\begin{array}{l}0.05 \\
0.05 \\
0.05 \\
0.06 \\
0.03 \\
0.04\end{array}$ & $\begin{array}{l}16 \\
14 \\
14 \\
17 \\
15 \\
15\end{array}$ & $\begin{array}{l}7 \\
7 \\
7 \\
7 \\
7 \\
8\end{array}$ & $\begin{array}{l}- \\
- \\
0.2 \\
- \\
-\end{array}$ & $\begin{array}{l}100 \\
110 \\
100 \\
100 \\
110 \\
130\end{array}$ & $\begin{array}{r}11 \\
13 \\
9 \\
10 \\
10 \\
11\end{array}$ & $\begin{array}{r}11.4 \\
9.4 \\
- \\
11.0 \\
9.3 \\
10.6\end{array}$ & $\begin{array}{l}0.27 \\
0.28 \\
0.27 \\
0.29 \\
0.27 \\
0.31\end{array}$ & $\begin{array}{l}2.6 \\
3.0 \\
- \\
3.3 \\
2.6 \\
2.7\end{array}$ & $\begin{array}{l}52 \\
54 \\
55 \\
51 \\
53 \\
53\end{array}$ & $\begin{array}{l}20 \\
19 \\
10 \\
19 \\
18 \\
21\end{array}$ & $\begin{array}{l}2 \\
2 \\
2 \\
2 \\
2 \\
2\end{array}$ & $\begin{array}{l}53 \\
56 \\
54 \\
56 \\
50 \\
99\end{array}$ \\
\hline
\end{tabular}

depression as compared with soil on the rim or outside the feature. Of the above elements, $\mathrm{Co}, \mathrm{Cu}, \mathrm{Fe}, \mathrm{Pb}, \mathrm{V}$, and $\mathrm{Zn}$ (fig. $15 \mathrm{~A}-\mathrm{H}$ ) are ones that are enriched in breccia pipe orebodies; thus, their enrichment in the soil suggests similar underlying mineralized rock. Nevertheless, the enhancement of so many elements within the collapse depression soil may reflect a false anomaly; that is, the depression may have permitted development of a thicker soil horizon containing more organic material, or $\mathrm{Fe}+$ Mn oxides, that adsorb metals. So, the anomalies may not reflect a mineralized breccia pipe but rather enrichment of metals due to better adsorption conditions.

Figure $15 I$ shows a comparison of $\mathrm{Cr}$ content in soils collected from two different soil depths. Soil samples were collected at both 4-in. and 8-in. depths and are plotted for comparison. Apparently neither level is consistently more enriched in $\mathrm{Cr}$ than the other (the results are similar for most of the other metals); so, the 4-in. depth is preferable to sample because of greater ease and speed in sample collection.

Although the soil overlying this structure is enriched in many metals relative to the surrounding terrain, whether the movement of ground water within a shallow sink hole could also cause such low-level metal enrichment, or whether the enrichment is due to upward movement of metals from a mineralized breccia pipe beneath, is unclear. In any event, the soil survey over collapse feature 571 appears favorable enough to merit additional study.

A helium soil-gas survey showed some anomalies along the rim of the collapse feature. Nevertheless, this feature had relatively low helium and the background was exceptionally low, as compared with other collapse features surveyed for helium on the Hualapai Reservation.

Bacillus cereus soil bacterial surveys were completed over collapse feature 571 (N.L. Parduhn, written commun., 1986). When penicillin concentrations of $10 \mathrm{ppm}$ were used during the $B$. cereus assay a distinct $B$. cereus low occurred over the collapse feature. This low is in contrast to surveys completed over known mineralized pipes that contain high concentrations over the breccia pipe orebody.

Collapse feature 571 AMT soundings did not yield results that were as encouraging as for many of the other collapses studied on the Hualapai Reservation. The 

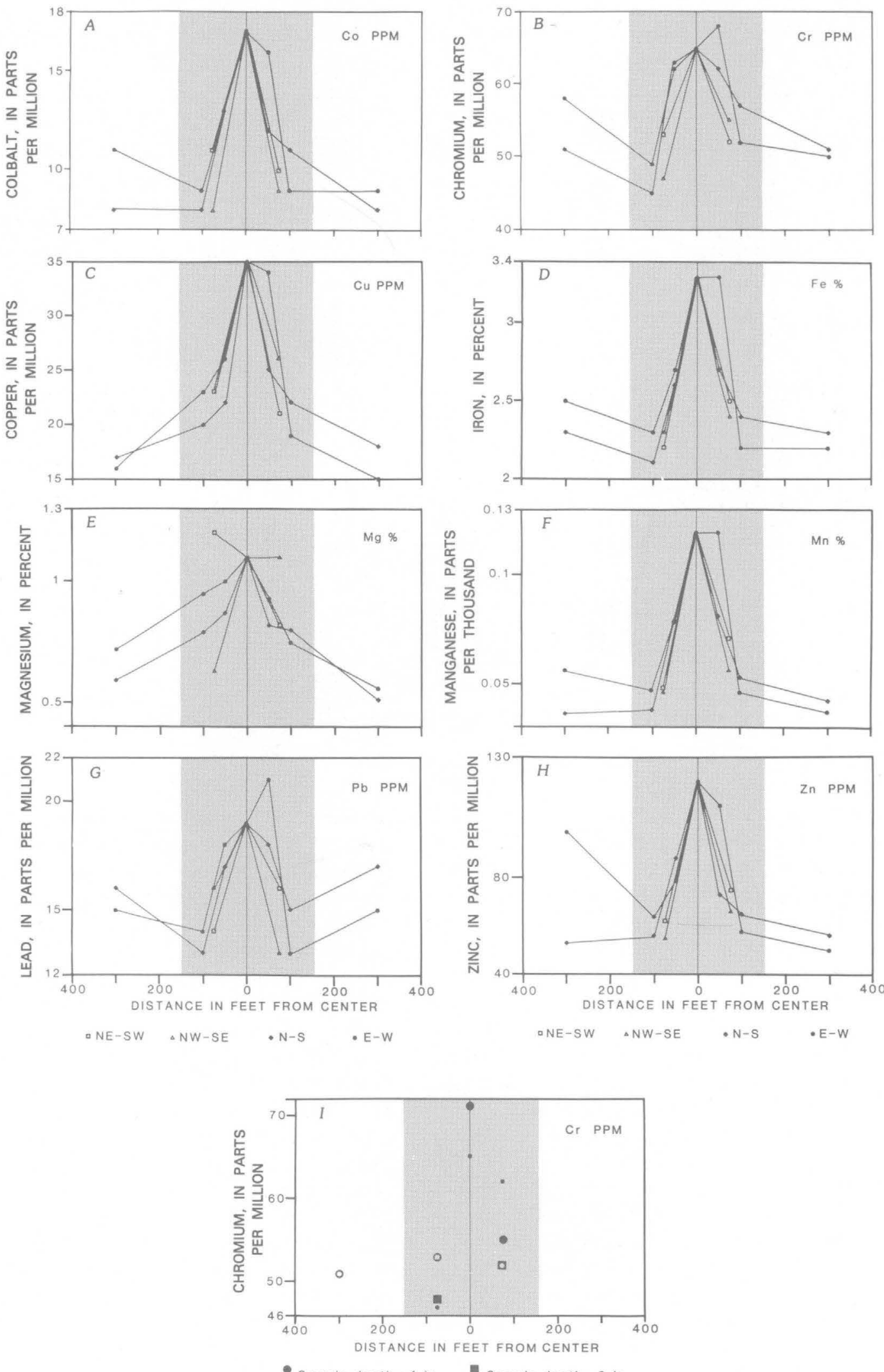


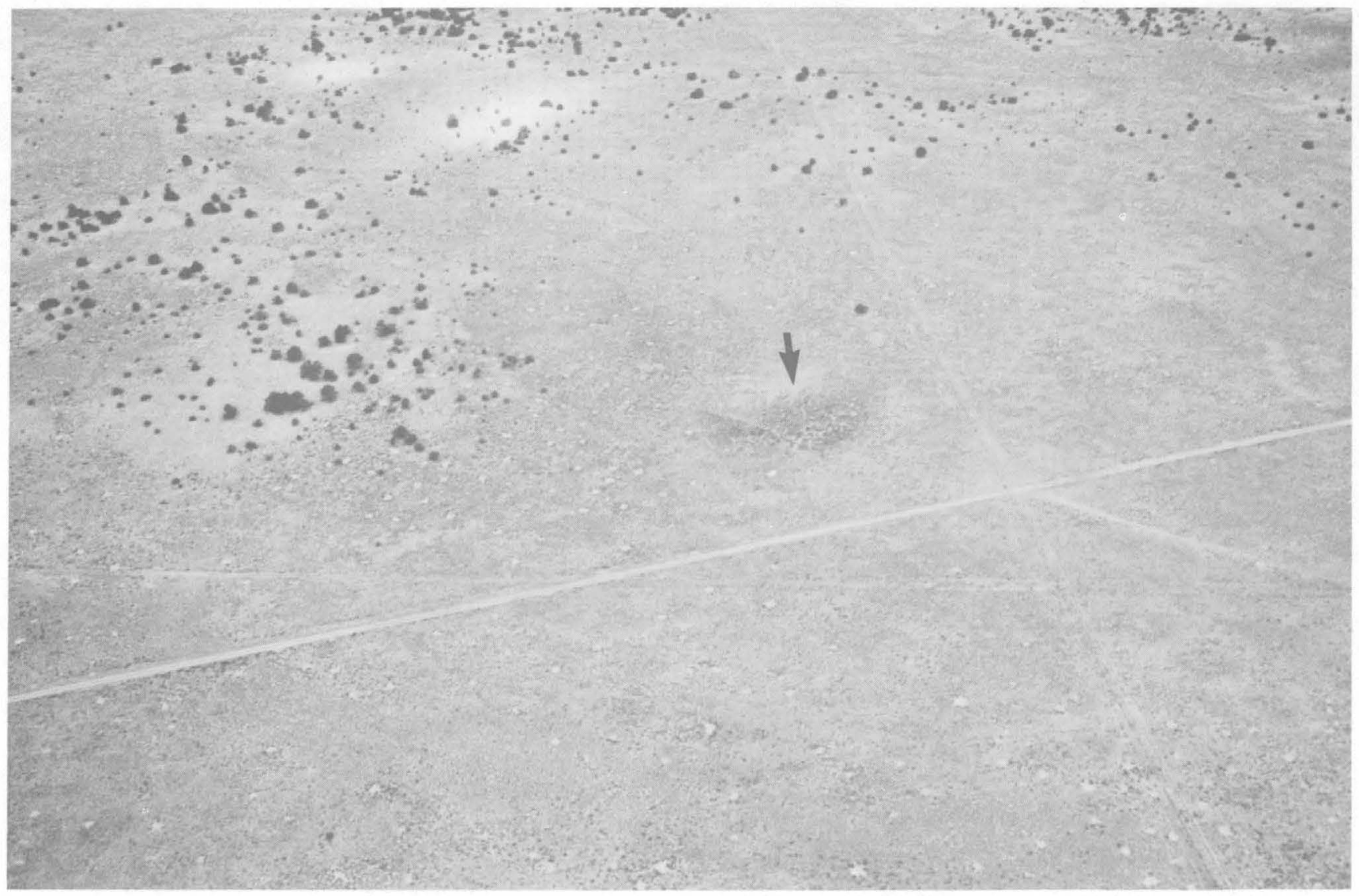

Figure 16. Collapse 572 (indicated by arrow), photographed from a helicopter, is a shallow depression surrounded by a white halo in the soil. The presently low center suggests recent dissolution.

conductivity anomalies that are present have a much lower intensity than those at other features, and instead of underlying the center of the collapse there appears to be a high under the rim on both sides of the traverse (Flanigan and others, 1986). The absence of a good conductivity high under the center of this feature suggests that the soil metal anomalies may be more of a reflection of increased soil development over a sink hole,

Figure 15 (facing page). Soil sampling survey results from collapse feature 571. Distance across the pipe is plotted on the abscissa; " 0 " represents the center of the pipe. The edge of the pipe is located $150 \mathrm{ft}$ from " 0 "; the pipe is $300 \mathrm{ft}$ in diameter (shown as shaded area). Concentrations of the metals: A, Co; $B, \mathrm{Cr} ; C, \mathrm{Cu} ; D, \mathrm{Fe} ; E, \mathrm{Mg} ; F, \mathrm{Mn} ; \mathrm{G}, \mathrm{Pb}$; and $H, \mathrm{Zn}$ are shown on the ordinate. A comparison is shown for $\mathrm{Cr}$ (I) between samples taken at 4-in. depth and at 8-in. depth. Samples from the same locality are shown with the same shape symbol, but different size. and subsequent metal enrichment, than a reflection of a mineralized breccia pipe. Additional studies should be completed over this feature before it is determined to be unfavorable for ore.

572-C?.-This feature appears as a dark, circular vegetation patch (fig. 16). It resembles a recent sink hole in that it does not appear to have a raised rim around it, although there is evidence of a white halo in the soil (fig. 16). There is not a high probability of a breccia pipe beneath this recent solution feature, although the probability certainly is higher than at features 538 and 539.

573-C4.-This feature (figs. 17A,B) is similar to 572 , but is more pronounced and circular. It is intermittently filled with water and probably represents a recent sink hole. The white rim of soil surrounding the feature suggests that this feature is more than a recent sink hole. A soil sampling survey was completed over the feature, but the results are not yet available. 


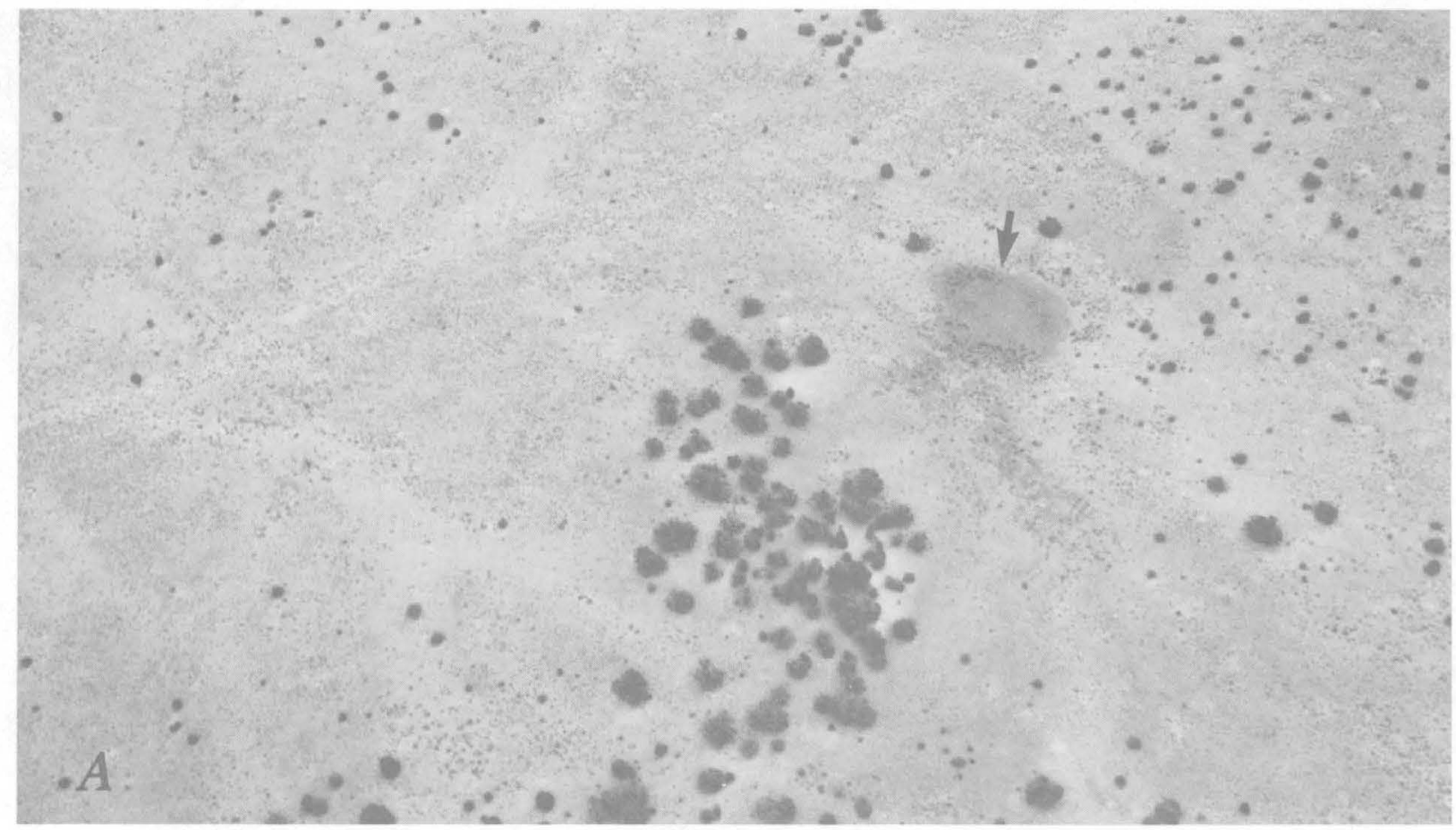

Figure 17. Collapse feature 573 (indicated by arrow). A, Photograph taken from a helicopter, suggests a modern sink hole. B, This low-altitude aerial photograph shows feature 573 (indicated by arrow) to be located on a ridge of Kaibab Limestone.

574-C4.-This collapse feature has a large reddish center surrounded by a somewhat elliptical tree-covered rim. It lies outside the Hualapai Indian Reservation by approximately $400 \mathrm{ft}$, as can be seen from the road and fence line that follows the reservation boundary (fig. 18). The ring of trees growing on a slightly raised rim suggests that this may be a deeper seated solution feature rather than just a recent sink into the Kaibab Limestone or Toroweap Formation.

$575-C ? .-$ This collapse feature is clearly a recent sink hole (fig. 19), as reflected by its name-Sink Tank. What is not clear, though, is whether this is a deeper seated solution feature that has long been a conduit for fluid movement. This fluid movement would have accentuated recent dissolution of the upper Paleozoic formations within the National Tank area, an actively spreading tectonic basin (P.W. Huntoon, written commun., 1986). Sink Tank is filled intermittently with water.

576-C?.-This feature appears from the air (fig. $20)$ to be a depression filled with reddish soil. There also appears to be an increase in tree growth; junipers are

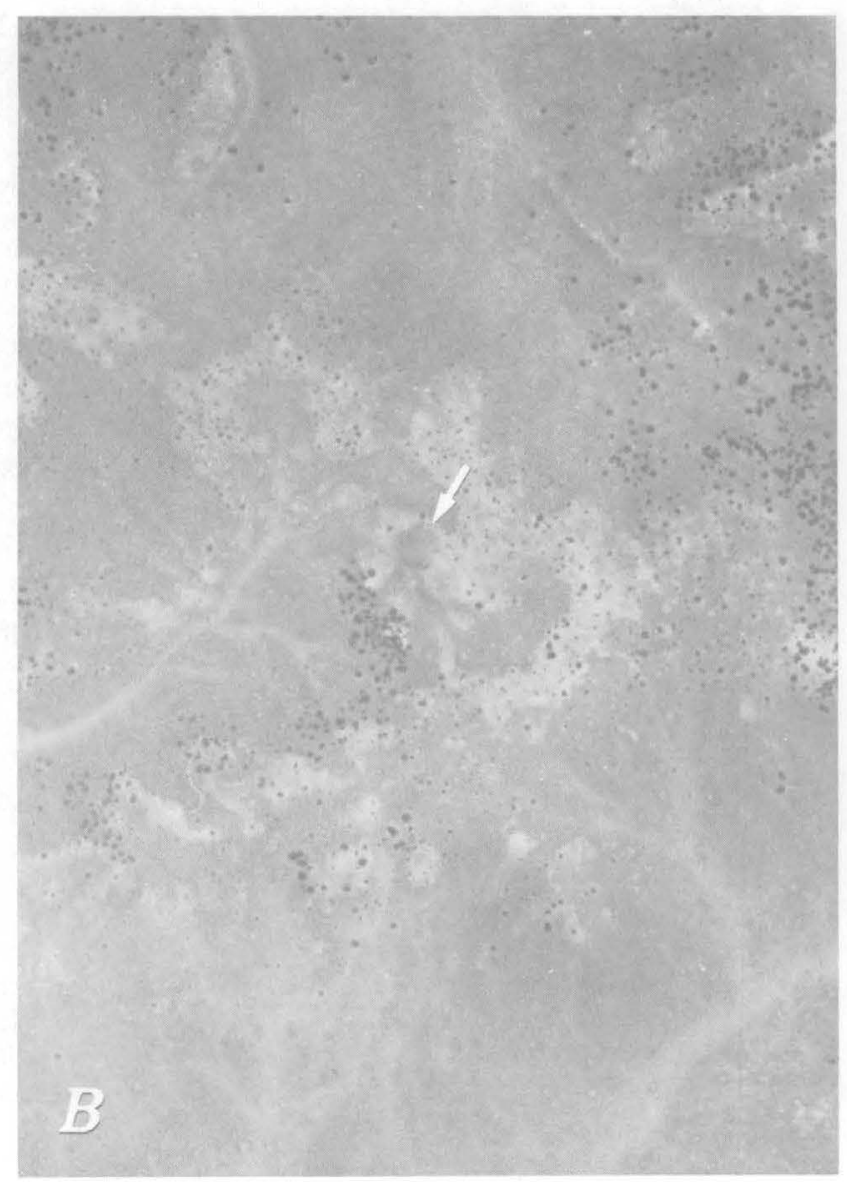




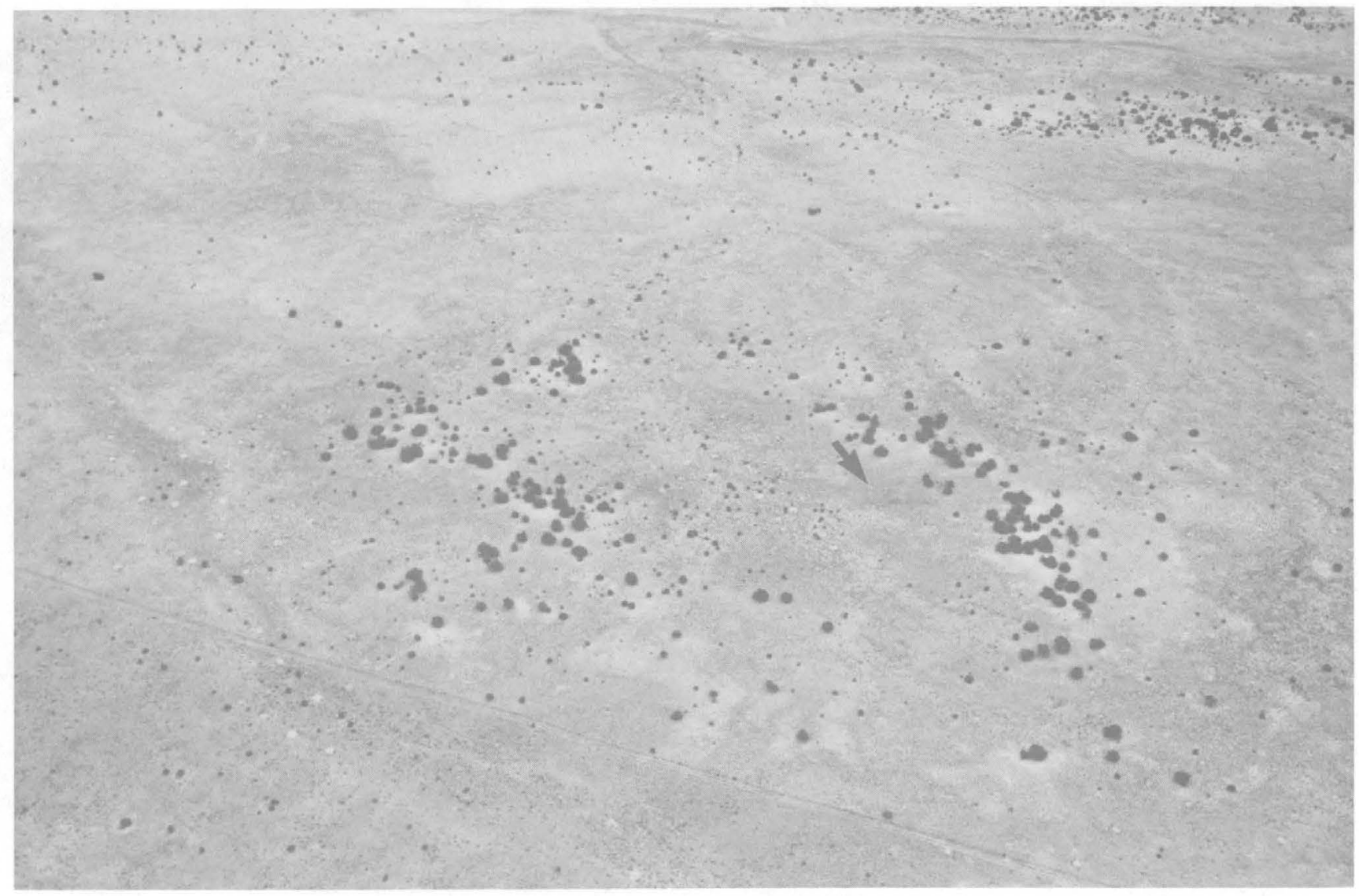

Figure 18. Collapse feature 574 (indicated by arrow), shown in this view from a helicopter, is not located on the Hualapai Indian Reservation, but is less than $400 \mathrm{ft}$ beyond the fence line. The structure is delineated by the circular ring of trees that probably lies along the ring fracture, which suggests a deeper seated feature rather than merely a recent sink hole. View is to the east.

more concentrated within this feature than outside it. The collapse may be only a sink hole, although a ridge with spotty outcrops of Kaibab Limestone borders part of the depression.

998-C4.-This collapse feature is merely a circular depression (fig. 21), but not a closed basin because it drains on the east side. It nevertheless is a conspicuous depression on the other three sides, and resembles the "amphitheaters" formed by erosion of breccia pipes in canyon areas.

1107-C2.-An elongate depression with a concentric drainage around a central hill forms this collapse (fig. 22). Beds of the Harrisburg Gypsiferous Member of the Kaibab Limestone dip inward toward a central hill. Such rock exposure is rare in the National Tank area and collapses 1107 and 1108, immediately to the southeast, are the only collapses in the National Tank area with inward-dipping beds. Soil-sample traverses made over this feature reveal no significant anomalies compared with background samples. The AMT soundings were also completed, but the results did not show a strongly conductive zone under collapse site 1107 (Flanigan and others, 1986).

1108-C2.-Collapse 1108 (fig. 22) sits adjacent to 1107 and exhibits a similar morphology of inwarddipping beds, although outcrop is more sparse at 1108 and there is no central hill. As with the soil-sample traverses at 1107 , those at 1108 show no strongly significant anomalies. Some elements did appear to be slightly enriched over 1108 as compared with the background, at least more so than at 1107 . The AMT soundings were similar to 1107 and showed no strongly conductive zones under 1108 (Flanigan and other, 1986). 1109-C?, 1110-C?, 1111-C?.-All three of these collapse features are considered questionable. This is particularly so with feature 1109 , which is near 1108 and 1107 , but is merely an arcuate hill with sparse junipers bordering a soil covered flat. Collapse 1110 has a nearly circular drainage around a hill that, when viewed from the air, visually appears quite circular. Kaibab Limestone on the central hill appears to be flat lying. Collapse 1111 


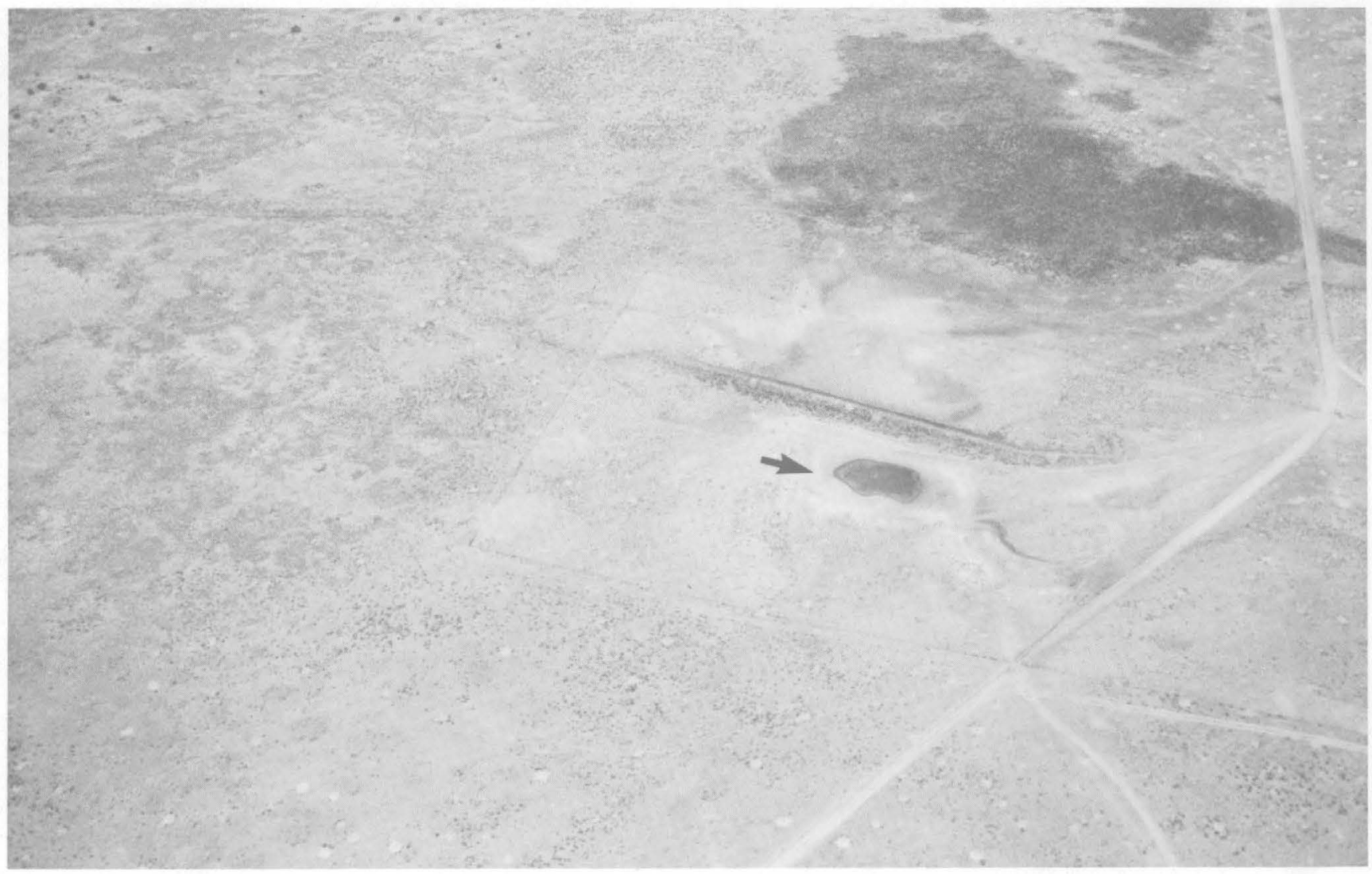

Figure 19. Photograph of Sink Tank (indicated by arrow) (collapse feature 575) taken from a helicopter. Whether there is a deeper seated breccia pipe under the more recent karst feature is not known. View is to the northwest.

is merely a soil-covered, treeless flat, three-quarters enclosed by a rim of trees.

1114-C4.-Collapse 1114 (fig. 23) is a slight depression whose grasses are greener than those on the surrounding flat area. This feature is perhaps more questionably a breccia pipe than some of the others in the C4 category. No geophysical surveys were made over this collapse, and the only geochemical surveys are soil for which the data are not yet available.

1115-C4.-This collapse is a relatively welldeveloped, closed basin (fig. 24). No geophysical surveys have been made on this collapse, and the only geochemical surveys are soil; computer processing of the data is not completed. This feature appears quite favorable for further exploration; it is the only collapse in the National Tank area where goethite nodules were found.

1116-C4.-This collapse forms a well-developed small depression filled by sagebrush amongst a terrain of sparse junipers (fig. 25). It is located adjacent to the northeast of 1115. This is the type of morphology, but on a much smaller scale, that is expressed on the surface by the Canyon pipe, a known uranium orebody.
1119-C4.-This collapse is morphologically identical to collapse 1116 (fig. 26). The depression is filled by reddish-brown soil and surrounded by scattered junipers. The center of the feature contains some red chert, whereas outside the depression the ridge contains typical white to cream Kaibab Limestone that caps most of the surrounding plateau. Because the exposed surrounding Kaibab at the same topographic horizon as that of the depression does not contain red chert, the center of the depression was probably downdropped from a higher stratigraphic position. Soil geochemistry traverses were made over this collapse, but the data have not yet been processed. The AMT soundings reflect a narrow vertical (about $1,800 \mathrm{ft}$ deep) conductive zone that appears to go to the Redwall Limestone, and the feature is therefore probably a breccia pipe.

1124-C?.-Collapse 1124 is very questionable and represents an irregular-shaped depression with grass and sagebrush surrounded by scattered junipers.

[Figs. 20-26 follow. "Conclusions" begins on page B32.] 


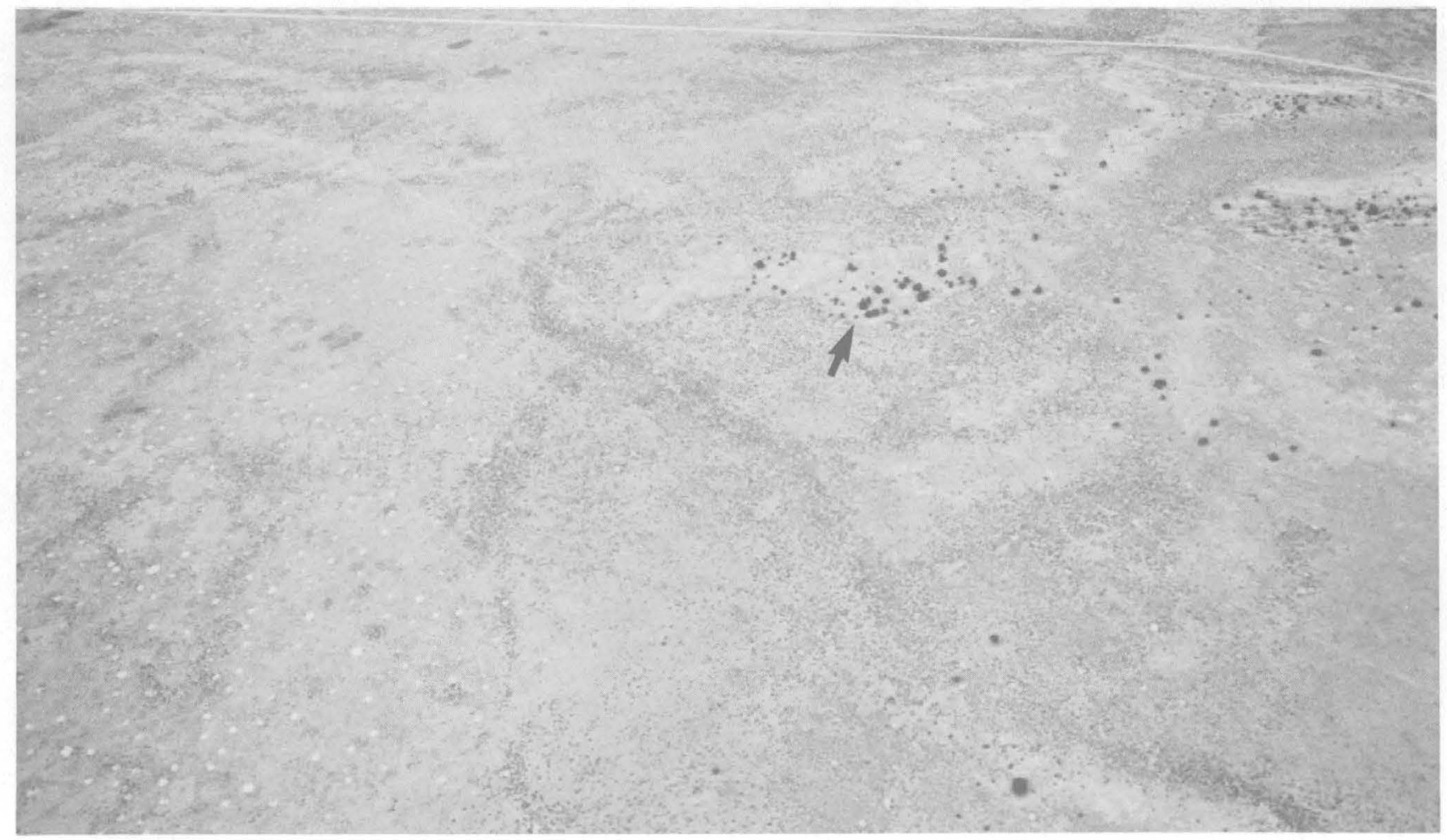

Figure 20. Photograph from a helicopter of collapse feature 576 (indicated by arrow). The surface morphology of the structure is a depression containing reddish-white soil. Note the stand of junipers in the right center of the photograph.



Figure 21. Photograph from a helicopter of collapse feature 998 (indicated by arrow). The only surface expression here that may indicate a possible underlying breccia pipe is the depression that is lower than the surrounding plateau on three sides. 


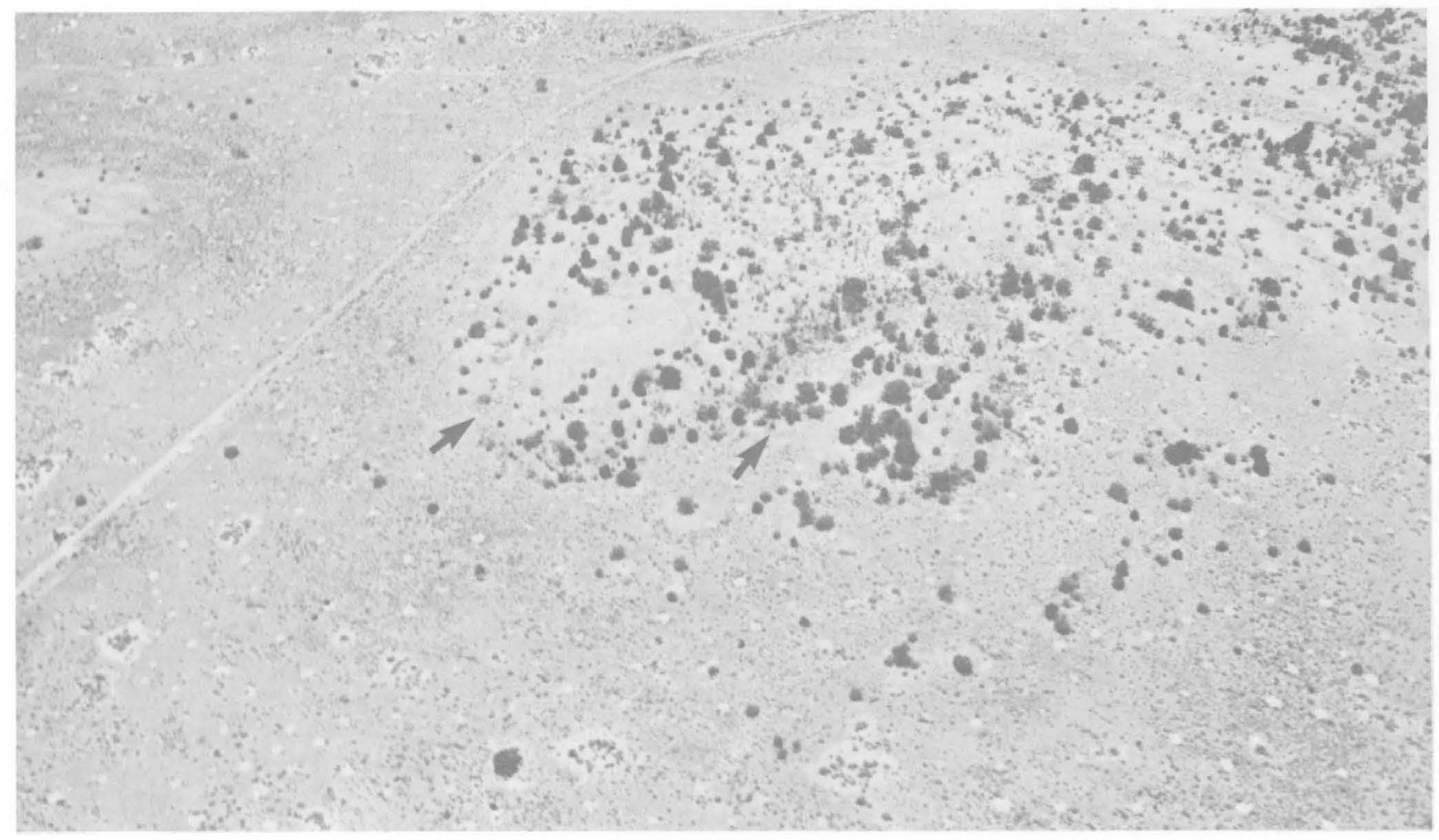

Figure 22. View from a helicopter to the southwest of collapse features 1107 (indicated by right arrow) and 1108 (indicated by left arrow). Both are basins elongated in an east-west direction.

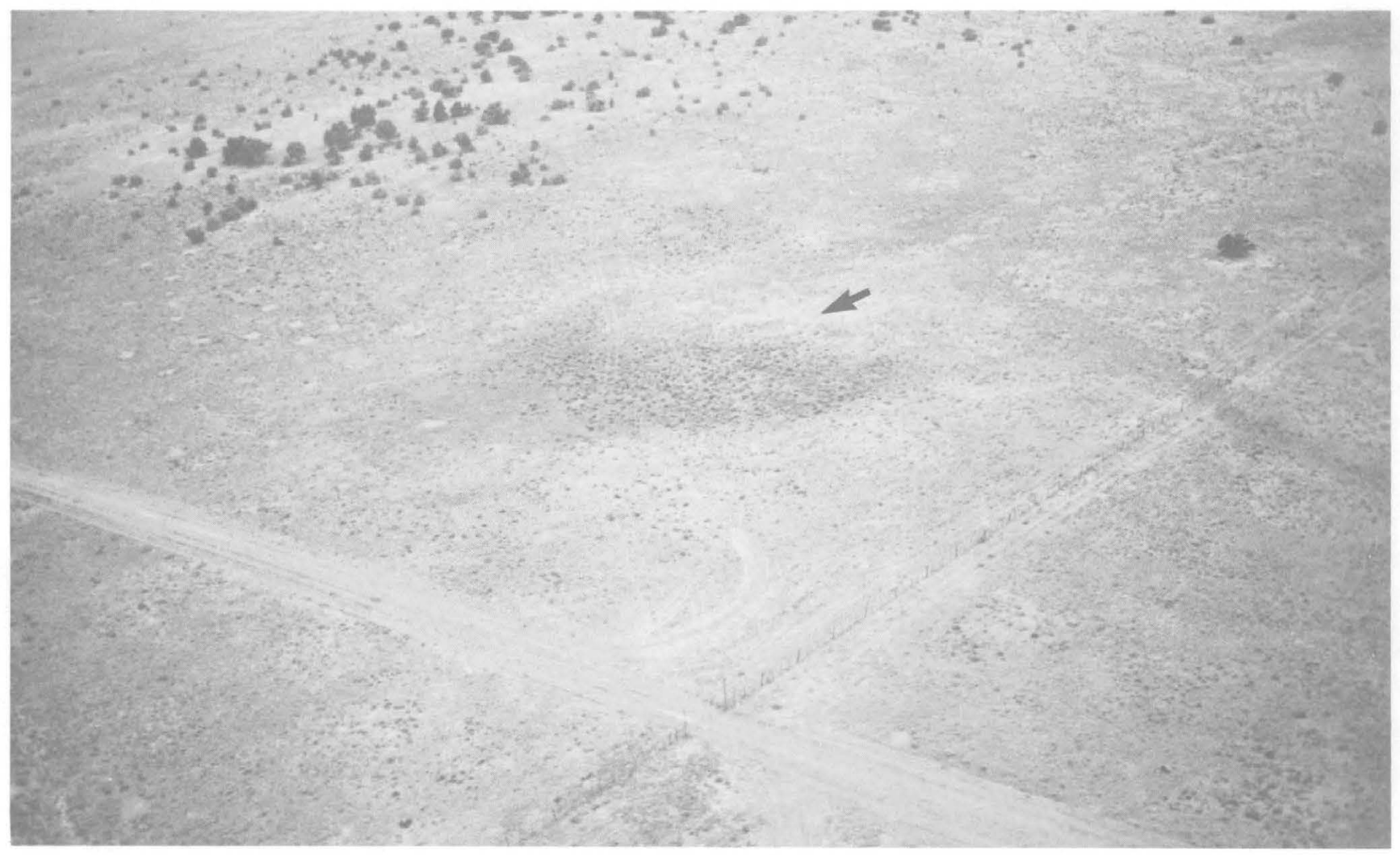

Figure 23. View from a helicopter to the southwest of collapse feature 1114 (indicated by arrow). This shallow depression with green grasses contrasts with the surrounding browner, less densely vegetated terrain. 


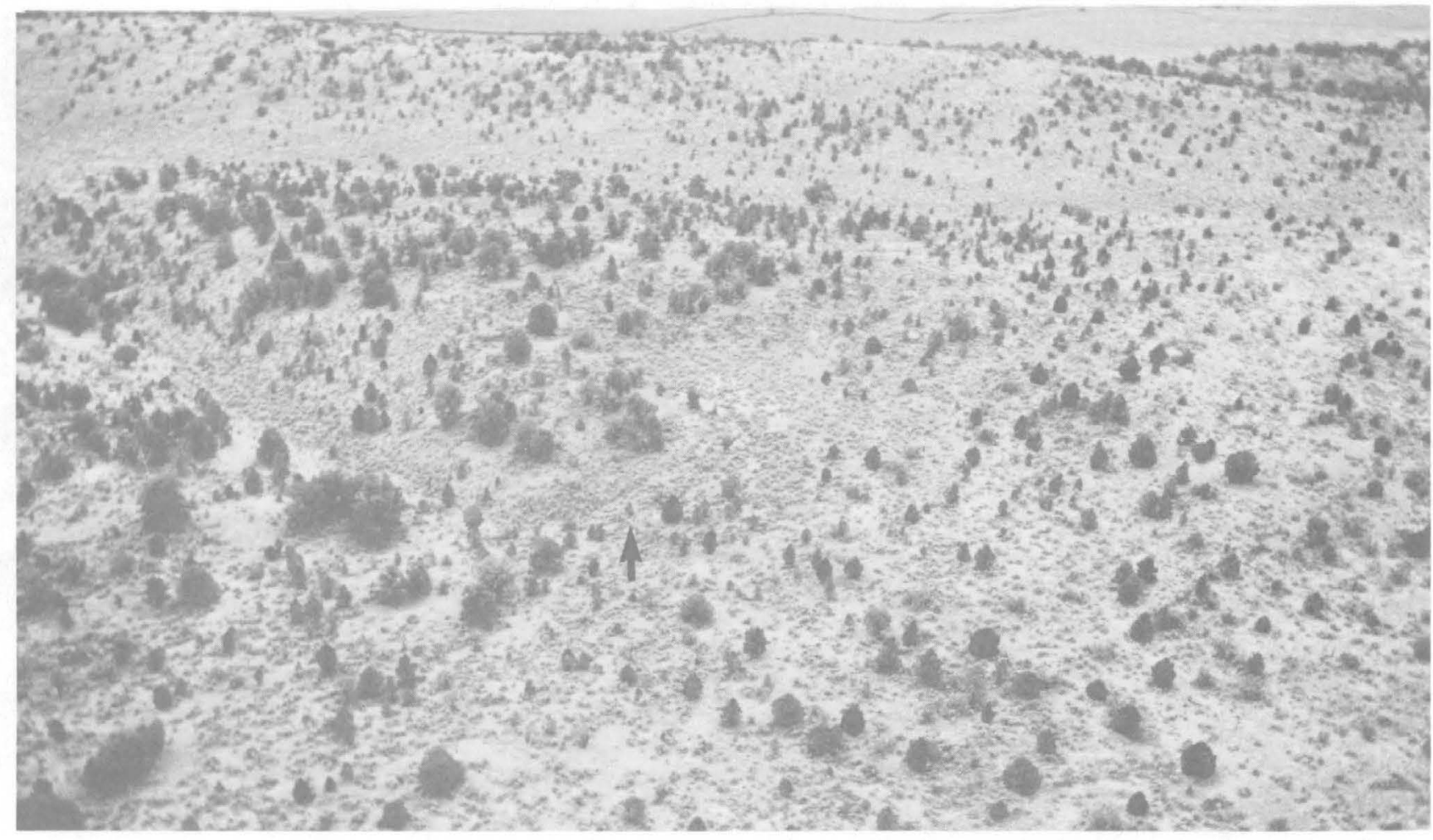

Figure 24. Collapse feature 1115 (indicated by arrow) forms a fairly well-developed closed depression with a lower lying drainage of sage enclosing (on three sides) a central hill of sparse junipers. View from a helicopter is to the south.

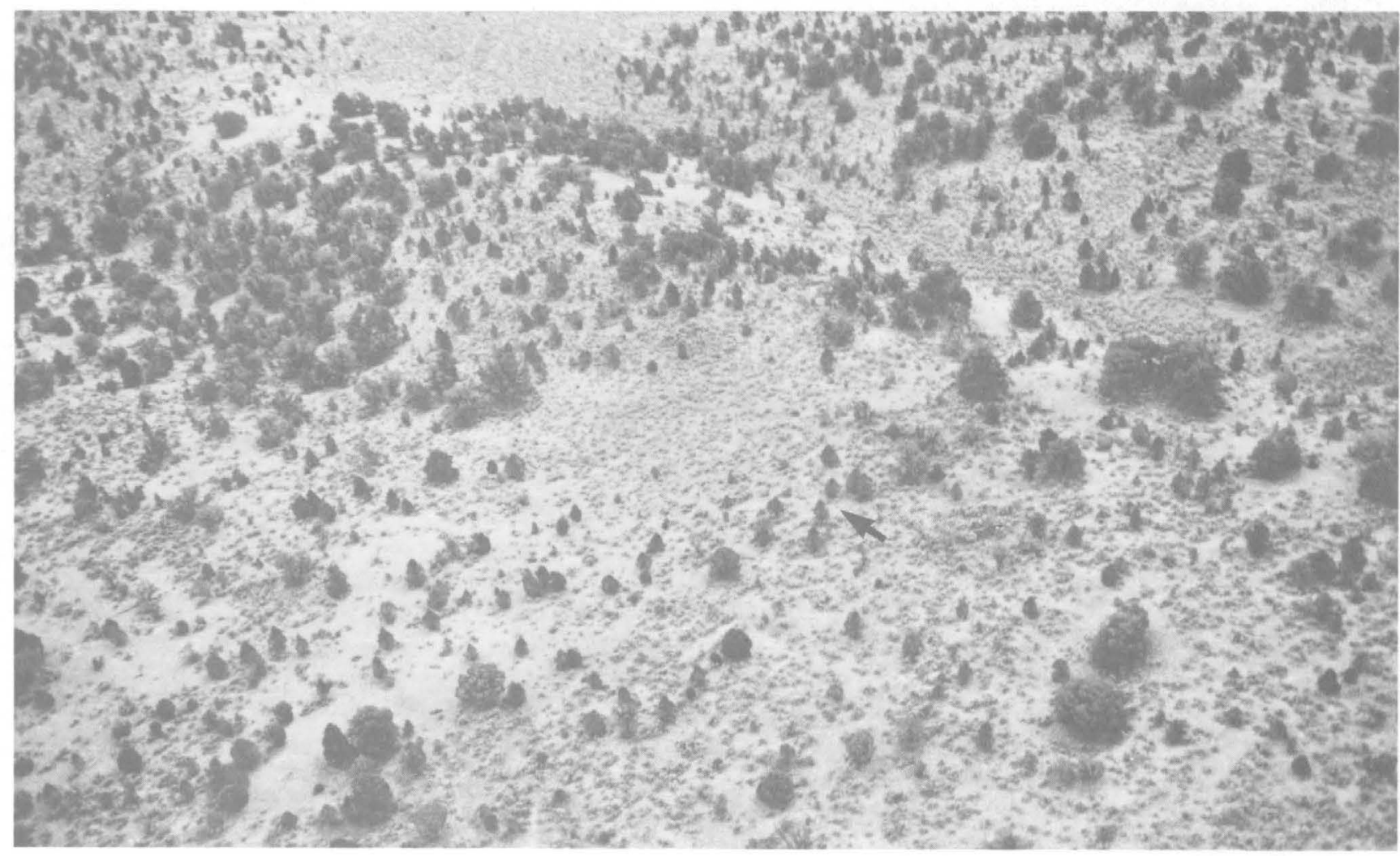

Figure 25. View from a helicopter to the south of collapse feature 1116 (indicated by arrow). This feature, adjacent and immediately east of collapse 1115, forms a slight depression of sage that contrasts with the surrounding terrain of sparse junipers. 




Figure 26. View from a helicopter to the east of collapse feature 1119 (indicated by arrow), which has a morphology and vegetation cover identical to collapse 1115.

\section{CONCLUSIONS}

The National Tank area has good access, particularly when compared with most other areas in northern Arizona where breccia pipes can be recognized. The asphalt Supai road bisects the area and would provide good mining access. Unfortunately, the area has little outcrop, no surface mineralized rock, and no anomalous gamma radioactivity in the soil or rock in excess of 2.5 times background.

Collapse features 562 and 564 (for locations see fig. 3) have been drilled by Rocky Mountain Energy and Energy Fuels, respectively. The persistence with which these features have been drilled over the past several years suggests strongly that they are both breccia pipes. Within the National Tank area, collapse features 570 and 569 most strongly resemble these drilled features. In addition, 531 and 534 also have some morphologic similarities.

In the National Tank area, several collapse features $(1116,1119$, and, to a lesser extent, 998) resemble the Canyon pipe but are somewhat smaller. The Canyon pipe is a known orebody expressed on the surface as a circular depression of grass and sage surrounded by Ponderosa pines. Perhaps this depression of grass and sage suggests that mineralized pipes produce a sufficient trace-metal halo above the orebody to prevent the growth of trees.

The reliability of soil geochemistry as a tool for locating breccia pipes has not yet been determined. The results from feature 571 leave doubt as to whether anomalous values over depressions might simply be a result of increased thickness of fine-grained soil, and hence more metal adsorption, compared with the surrounding terrain where the "soil" tends more to be fine-grained chips of Kaibab Limestone. Yet of the 33 elements determined for collapse feature 534, only Co, $\mathrm{Cu}, \mathrm{Fe}, \mathrm{Mn}, \mathrm{Ni}, \mathrm{Pb}$, and $\mathrm{Zn}$ appear to be significantly enriched over the collapse as compared with the background terrain. Because these metals are all ones that are enriched in breccia pipe orebodies, soil geochemistry may be a useful tool in breccia pipe exploration.

Audio-magnetotelluric (AMT) soundings appear to show vertical conductive zones over several of the more morphologically favorable collapse structures. The AMT soundings are very favorable for collapse feature 
570 , in that they closely resemble the results from the EZ-2 survey, a known breccia pipe orebody (Flanigan and others, 1986). In fact, 570 appears to even have a slight tilt to the upper part, as does EZ-2. The AMT results for 569 are encouraging, whereas those for 531, 571,1107 , and 1108 are not, although the $571 \mathrm{~W}-\mathrm{E}$ traverse closely resembles the results from the $562 \mathrm{~N}-\mathrm{S}$ traverse (Flanigan and others, 1986). The TDEM data from a geophysical survey on collapse structure 534 show a distinct change in resistivity at a depth of about $960 \mathrm{ft}$ $(290 \mathrm{~m})$; this is approximately the same depth as the top of the Seligman Member of the Toroweap Formation in the center of the Mohawk Canyon breccia pipe (Wenrich and others, 1985). Outside of the Mohawk Canyon pipe the top of the Seligman Member lies about $100 \mathrm{ft}$ stratigraphically higher. This suggests that collapse structure 534 is downdropped to the same level as the Mohawk Canyon pipe, which is lower than the surrounding terrain, and thus is probably a breccia pipe. Ground magnetometer traverses over feature 569 show dipole highs and lows that would be expected over a narrow vertical body of rock heterogeneous from the surrounding rock.

Initial results from $B$. cereus surveys for most of the collapse features did not appear particularly useful (N.L. Parduhn, written commun., 1986). Then penicillinamended agars were prepared and many of the B. cereus traverses showed significant highs over collapses compared with the background. Helium soil-gas surveys over several collapse structures were not as promising as some of the other techniques.

Within the National Tank area two northeast alignments of pipes are quite striking. Toward the top of the area six collapse features $(1115,1116,1119,539,538$, and 534) are aligned in a N. $56^{\circ}$ E. direction. At the bottom of the National Tank area, four collapses (570, 569,1114 , and 574) are perfectly aligned in nearly the same direction $-\mathrm{N} .53^{\circ} \mathrm{E}$. This alignment may be useful for exploration; that is, if collapse feature 570 is a mineralized breccia pipe, which it well may be, then there is a good chance that 569,1114 , and 574 are also. The northeast alignments on the Marble Plateau mapped by Sutphin and Wenrich (1983) tend to be closer to N. $40^{\circ}$ E. Perhaps the basement structures, which they suggest control the pipe locations, have been slightly rotated westward toward the Grand Wash Cliffs (edge of the Colorado Plateau).

Of the 25 features described from the National Tank area, collapses 534, 569, and 570 appear to have the most potential as mineralized breccia pipes. Collapse features 1107 and 1108 have concentrically inwarddipping beds and thus have excellent potential for being breccia pipes rather than recent collapses. Features 525, $531,571,572,573,574,575,576$, and 1114 are undoubtedly at least recent karst features, but the possible presence of underlying breccia pipes still needs to be assessed. Features 537, 538, 539, 998, 1109, 1110, 1111, and 1124 are not even certain to be collapse structures. Additional surveys and techniques are needed for all features. Additional soil, helium, Bacillus cereus, magnetometer, AMT, and TDEM surveys over all features would be most helpful. Of these techniques, the natural source, scaler audio-magnetotelluric (AMT) is the most promising.

\section{REFERENCES CITED}

Billingsley, G.H., Jr., and Huntoon, P.W., 1983, Geologic map of Vulcans Throne and vicinity, western Grand Canyon, Arizona: Grand Canyon Natural History Association, scale $1: 48,000$.

Chenoweth, W.L., 1986, The Orphan Lode mine, Grand Canyon, Arizona-A case history of a mineralized, collapsed breccia pipe: U.S. Geological Survey Open-File Report 86-510, 63 p.

Flanigan, V.J., Mohr, Pam, Tippens, Charles, and Senterfit, Michael, 1986, Electrical character of collapse breccia pipes on the Coconino Plateau, northern Arizona: U.S. Geological Survey Open-File Report 86-521, 50 p.

Foord, E.E., McKee, E.D., and Bowles, C.G., 1978, Status of mineral resource information for the Shivwits Plateau, Parashant, Andrus, and Whitmore Canyons, and Kanab Canyon areas, Grand Canyon, Arizona: U.S. Geological Survey Administrative Report for the National Park Service, $30 \mathrm{p}$.

Gornitz, Vivian, and Kerr, P.F., 1970, Uranium mineralization and alteration, Orphan mine, Grand Canyon, Arizona: Economic Geology, v. 65, p. 751-765.

Huntoon, P.W., Billingsley, G.H., Jr., and Clark, M.D., 1981, Geologic map of the Hurricane fault zone and vicinity, Western Grand Canyon, Arizona: Grand Canyon Natural History Association, scale 1:48,000.

1982, Geologic map of Lower Granite Gorge and vicinity, western Grand Canyon, Arizona: Grand Canyon Natural History Association, scale 1:48,000.

Ludwig, K.R., Rassmussen, J.D., and Simmons, K.R., 1986, Age of uranium ores in collapse-breccia pipes in the Grand Canyon area, northern Arizona: Geological Society of America Abstracts with Programs, v. 18, no. 5, p. 392.

Reimer, G.M., 1985, Helium soil gas survey of a collapse feature on the Hualapai Indian Reservation, Arizona: U.S. Geological Survey Open-File Report 85-394, 15 p.

Senterfit, R.M., Mohr, P., and Horton, R., 1985, Geophysical studies of breccia pipe locations on the Hualapai Indian Reservation, Arizona: U.S. Geological Survey Open-File Report 85-400, 30 p. 
Sutphin, H.B., 1986, Occurrence and structural control of collapse features on the southern Marble Plateau, Coconino County, Arizona: Northern Arizona University M.S. thesis, 139 p.

Sutphin, H.B., and Wenrich, K.J., 1983, Structural control of breccia pipes on the southern Marble Plateau, Arizona: U.S. Geological Survey Open-File Report 83-908, 6 p., 2 plates, scale 1:50,000.

Sutphin, H.B., Wenrich, K.J., and Verbeek, E.R., 1983, Structural control of breccia pipes on the southern Marble plateau, Arizona: Geological Society of America Abstracts with Programs, v. 15, no. 5, p. 376.

Van Gosen, B.S., and Wenrich, K.J., 1989, Ground magnetometer surveys over known and suspected breccia pipes on the Coconino Plateau, northwestern Arizona: U.S. Geological Survey Bulletin 1683-C, 31 p.

Verbeek, E.R., and Wenrich-Verbeek, K.J., 1980, Description of collapse structures by physiographic province, in Wenrich-Verbeek, K.J., Spirakis, C.S., Billingsley, G.H., Hereford, R., Nealey, L.D., Ulrich, G.E., Verbeek, E.R., and Wolfe, E.W., National Uranium Resource Evaluation, Flagstaff quadrangle, Arizona: U.S. Department of Energy Open-File Report PGJ-014 (82), p. 25-31, plate $10 \mathrm{a}$.

Wenrich, K.J., 1985, Mineralization of breccia pipes in northern Arizona: Economic Geology, v. 80, p. 1722-1735.
Wenrich, K.J., Billingsley, G.H., and Van Gosen, B.S., 1990, Potential breccia pipes in the Mohawk Canyon area, Hualapai Indian Reservation, Arizona: U.S. Geological Survey Open-File Report 90-15, 71 p.

Wenrich, K.J., and Sutphin, H.B., 1987, Unique minerals from Redwall Limestone caves, Arizona-Their association with mineralized breccia pipes: Geological Society of America Abstracts with Programs, v. 19, no. 6, p. 463.

1989, Lithotectonic controls necessary for formation of a uranium-rich, solution-collapse breccia-pipe province, Grand Canyon region, Arizona: U.S. Geological Survey Open-file Report 89-173, 33 p.

Wenrich, K.J., Van Gosen, B.S., Balcer, R.A., Scott, J.H., Mascarenas, J.F., Bedinger, G.M. and Burmaster, Betsi, 1988, A mineralized breccia pipe in Mohawk CanyonLithologic and geophysical logs: U.S. Geological Survey Bulletin 1683-A, 66 p.

Wenrich-Verbeek, K.J., and Verbeek, E.R., 1980, General description of breccia pipes, in Wenrich-Verbeek, K.J., Spirakis, C.S., Billingsley, G.H., Hereford, R., Nealey, L.D., Ulrich, G.E., Verbeek, E.R., and Wolfe, E.W., National Uranium Resource Evaluation, Flagstaff quadrangle, Arizona: U.S. Department of Energy OpenFile Report PGJ-014 (82), p. 17-25. 


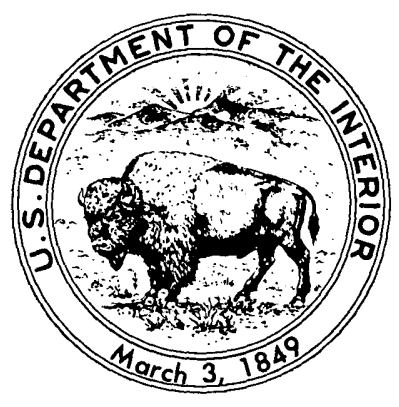

